\title{
SPATIAL HETEROGENEITY IN KNOWLEDGE, INNOVATION, AND ECONOMIC GROWTH NEXUS: CONCEPTUAL REFLECTIONS AND EMPIRICAL EVIDENCE
}

\author{
Roberta Capello \\ Politecnico di Milano, Department of Architecture, Built Environment and Construction \\ Engineering, Piazza Leonardo da Vinci 32, 20133, Milan, Italy.E-mail: roberta.capello@polimi.it
}

\section{Camilla Lenzi}

Politecnico di Milano, Department of Architecture, Built Environment and Construction

Engineering, Piazza Leonardo da Vinci 32, 20133, Milan, Italy.E-mail: camilla.lenzi@polimi.it

\begin{abstract}
By drawing on the Schumpeterian distinction between invention (i.e., new ideas and knowledge creation) and commercialization of new ideas (i.e., innovation), this paper shows that knowledge and innovation are both important drivers of economic growth, but have heterogeneous spatial impacts. In particular, the growth benefits accruing from knowledge seem rather selective and concentrated across space whereas the growth benefits generated by innovation seem more diffusive, and regions innovating in the absence of a strong local knowledge base can be as successful as more knowledge-intensive regions in turning innovation into a higher growth rate, possibly by exploiting local informal knowledge and/or knowledge spillovers. These results are of great importance for the design of research and innovation policies within the frame of the Europe 2020 strategy.
\end{abstract}

\section{INTRODUCTION}

This paper studies the role played by knowledge and innovation in regional economic growth. Much has already been written in the literature on this relationship, and opinions largely converge on the importance of these elements for regional performance. ${ }^{1}$

This paper therefore belongs within a well-documented literature tradition and aims to contribute to it by providing new evidence on spatial heterogeneity in the interplay between knowledge and innovation, and by assessing their (spatially differentiated) impacts on regional growth.

In particular, this paper claims that the capacity of regions to exploit (and mix) knowledge and innovation successfully in order to achieve higher paces of economic growth may differ substantially among regions, and that less knowledge-intensive innovative regions can succeed just as much as more knowledge-intensive regions in exploiting innovation to achieve higher economic performances.

Focusing on technological change as the innovation paradigm to be studied, this paper separates knowledge from innovation by drawing on the Schumpeterian distinction between invention (i.e., a new idea, a new piece of knowledge) and commercialization of a new idea (i.e., innovation) (Schumpeter, 1934, 1942). With this distinction in mind, the paper conceptually treats "R\&D and patents" as sources of new (formal) knowledge that may lead to innovation when commercially exploited. Empirically, this distinction is made possible by a rich database on the share of firms developing product and/or process innovation at the regional level, where innovation is conceived as the result of either formal or informal knowledge embedded in human capital, if not of knowledge spillovers. 
This paper aims to demonstrate that, on average, both knowledge and innovation are crucial, albeit different, drivers of economic growth. However, since knowledge and innovation may mix in space in a variety of ways, this paper seeks to show that the growth benefits accruing from innovation do not always match the strength of the formal local knowledge base. In so doing, this paper adds to the literature on knowledge, innovation, and regional growth in three main directions.

First, at the conceptual level, the paper separates out the impact of knowledge on economic growth from the impact of innovation; regions may in fact benefit from innovation without being knowledge-intensive creators, or they may take advantage of knowledge creation, without fully exploiting their knowledge capacity to innovate. In this way, the paper contributes to research on the conceptualization of innovative processes at the local level. In fact, by distinguishing invention (i.e., knowledge creation) from commercialization (i.e., innovation), our approach directly challenges the view that locally created formal knowledge unavoidably leads to local innovation and, more importantly, that local innovation takes place only because of local formal knowledge availability. While the crucial role of creative efforts, learning processes, interactive and cooperative atmospheres, that is, knowledge creation activities, in achieving productivity gains and enhanced economic performance is almost indisputable, the paper argues that, at the spatial level, the knowledge/innovation nexus is far from straightforward. Although lacking strong local formal knowledge creation capabilities, several regions may achieve not negligible innovation and economic performances by exploiting knowledge externalities and/or local informal knowledge.

Second, at the empirical level, the paper provides brand new data on knowledge, innovation, and growth patterns for 262 regions of 27 European Union member states. The paucity and/or low quality of regional innovation data may be the reason for the scarcity of approaches separating invention from innovation at the local level, especially in the European case (Hollanders, Tarantola, and Loschky, 2009).

Finally, our conceptual hypotheses and empirical results are of high importance for current efforts to design research and innovation policies within the frame of the Europe 2020 strategy for the smart growth of the European Union and its regions (EC, 2010a, $2010 \mathrm{~b}, 2010 \mathrm{c}$ ). Whereas previous policy efforts have mostly concentrated on supporting knowledge creation activities as the chief enablers of higher economic performance, and implicitly on knowledge-intensive regions as prominent players in this regard, our results suggest that innovative regions should not be neglected, because they show comparable growth potential. Targeting these regions with dedicated innovation policies therefore seems crucial to have them fully contributing to the achievement of the Europe 2020 strategy goals.

The rest of the paper is organized as follows. Section 2 comments on the relevant literature about knowledge, innovation, and regional growth and, accordingly, formulates the research hypotheses. Section 3 sets out the empirical framework and describes knowledge and innovation patterns in European regions. Section 4 reports and discusses our empirical findings. Section 5 provides a possible explanation for the lack of the knowledgeinnovation nexus in some regions. Section 6 concludes by outlining important policy implications deriving from this work.

\section{REFLECTIONS FROM THE LITERATURE AND TESTABLE HYPOTHESES}

\section{Knowledge, Innovation and Regional Growth Nexus: State of the Art in the Existing Literature}

Over time, a large body of theoretical and empirical studies have considerably expanded and augmented the scientific understanding of knowledge and innovation 
processes in space, and they have been highly successful in identifying the territorial preconditions and local elements that can support them.

The advance and diffusion of endogenous growth theory (Grossman and Helpman, 1990; Romer, 1990; Aghion and Howitt, 1998; Howitt, 2000; Acemoglu, Aghion, and Zilibotti, 2006; Ertur and Koch, 2011) and New Economic Geography (NEG) (following the seminal contribution by Krugman in 1991) since the early-1990s have certainly generated renewed interest in the theoretical and empirical literature on regional growth in the past two decades. The emphasis placed on the role of knowledge and innovation as sources of increasing returns and, possibly, divergent (club) growth patterns, as earlier highlighted in evolutionary Schumpeterian contributions (for a review see Fagerberg, 2003), has in fact led to fertile and extensive contributions to the debate of regional convergence, especially in the European context (Rodríguez-Pose and Fratesi, 2004; Ramajo et al., 2008).

In parallel, since the influential papers by Jaffe $(1986,1989)$ and Griliches (1990), empirical tests of knowledge production functions, implemented at the national, regional, and firm levels, have provided robust evidence of the key role of knowledge inputs (namely, R\&D expenditures) in generating knowledge outputs (namely, patent intensity) at all levels of analysis (for a regional approach, see among the many others Crescenzi, 2005; Rodríguez-Pose and Crescenzi, 2008; Sterlacchini, 2008; Marrocu, Paci, and Usai, 2013). Importantly, they have confirmed the unbalanced spatial distribution of knowledge production and they have opened the debate on the geographical reach of knowledge flows, as well as on the main mechanisms and channels directing them (Jaffe, Trajtenberg, and Henderson, 1993; Acs, Audretsch, and Feldman, 1994; Audretsch and Feldman, 1996; Anselin, Varga, and Acs, 2000; Autant-Bernard, 2001; Moreno, Paci, and Usai, 2005; Fritsch and Slavetch, 2007; Breschi and Lissoni, 2009; Capello and Caragliu, 2012).

The capacity of generating local knowledge, and of turning knowledge into growth, has long been identified with the presence of territorial conditions in the area: the role of soft elements like interaction, synergy, and cooperation among local actors has been highlighted as fundamental source of collective learning processes and, hence, new knowledge creation at the local level, eventually leading to innovation. Local "milieux"consisting of network relations (long-distance and selective relationships), interaction, creativity, and recombination capability nourished by trust, social capital, and agglomeration effects-have been indicated as primary loci for the creation of knowledge (Camagni, 1991; Perrin, 1995; Capello, 1999; Keeble and Wilkinson, 1999, 2000). Similarly, the "learning" region, that is, a region able to combine existing but dispersed know-how, interpretations of market needs, information flows with intellectual artifacts such as theories and models, has been identified as the place where such cognitive processes play a vital role (Lundvall and Johnson, 1994). Likewise, the regional innovation system approach has highlighted the importance of an efficient combination of a subsystem of knowledge generation and diffusion (knowledge infrastructure dimension) with a subsystem of knowledge application and exploitation (business dimension), which is made up of the companies located in the region, and where intense interactions and the circulation of knowledge, human capital, and resources within and between the subsystems are the success conditions for local innovation (Trippl, 2010). Also, in specific streams of literature, such as the "milieux innovateurs" theory (Camagni, 1991), innovative areas by definition are expected to register higher productivity increases.

Interestingly, all these contributions consistently emphasize the crucial role of knowledge in regional growth and share the idea that the higher the local (formal) knowledge endowment the better the local economic performance. Consistently with the Schumpeterian 
tradition, innovation is viewed as the outcome of investments in very costly and risky research activities. Accordingly, the empirical tests are mostly based on the use of R\&D statistics (or patent counts) as proxies for innovation outcomes, returning a highly concentrated picture of knowledge creation (and thus innovation) activities in space (see among many others Acs et al., 1994; Anselin et al., 2000; Howitt, 2000; Acemoglu et al., 2006; Fritsch and Slavetch, 2007; Rodríguez-Pose and Crescenzi, 2008; Sterlacchini, 2008; Ertur and Koch, 2011; Marrocu et al., 2013).

If the relationship among knowledge, innovation, productivity increases, and economic growth is largely undisputable, it is nevertheless true that some regions may be more able than others to grasp the advantages stemming from knowledge and innovation. From an evolutionary perspective, in fact, knowledge creation and innovation are highly cumulative processes leading to a markedly differentiated cognitive base, absorptive capacity and potential for learning across actors and regions (Iammarino and McCann, 2006), explaining the agglomeration of firms in high-tech clusters (among others, see Keeble, 1990; Sternberg, 1996a). Therefore, the capacity to exploit knowledge and innovation for strategic purposes is not equally distributed among firms, institutions, and, in general, regions (Capello, 1994), suggesting that the link between formal knowledge and innovation, and their impact on economic growth, may be much complex and heterogeneous at the regional level (and more than at the national level), and regions may succeed in innovating and growing although they lack strong local (formal) knowledge creation capabilities (Capello and Lenzi, 2013a). Sternberg (1996b), for example, suggests that the link between formal knowledge (in the form of public R\&D expenditures) and innovative performance is somewhat weaker in countries adopting a diffusion-oriented approach to technology policies (Ergas, 1987) than in countries adopting a mission-oriented approach to technology policy.

In some cases, regions can innovate on the basis of external knowledge, acquired through networking with leading regions, and of specific know-how in local application sectors. The history of technology and innovation is rich with examples: the fax machine, first developed in Germany, was turned into a product successful worldwide by Japanese companies. Similarly, the antilock brake system (ABS) was invented by U.S. car makers but became prominent primarily due to German automotive suppliers (Licht, 2009). More in general, there may be regions with weak internal formal knowledge creation capacity but which are able to leverage on external knowledge sources or on internal informal knowledge sources and to develop innovation so to achieve higher economic growth rates.

On the one hand, R\&D investments are indicators of what can be termed "analytical" and "formal" knowledge (Asheim and Coenen, 2005; Asheim and Hansen, 2009), and thus provide a highly selective, and possibly unbalanced, description of the knowledge sources. Innovation processes increasingly rely upon a mix of differentiated knowledge sources that tend to vary with specific characteristics of innovative agents. Conte and Vivarelli (2005) and Piergiovanni, Santarelli, and Vivarelli (1997) specifically show that the importance of formal knowledge tends to decrease for smaller firms and in more traditional sectors, which instead rely more on technologies embodied in machinery and equipment on the one hand, and informal knowledge embedded in professionals on the other. Moreover, R\&D and patents are indicators of specific innovation efforts stemming from formal knowledge. They neglect all innovative efforts that can be developed either in the form of process, marketing, and organizational innovations or in the form of product innovation not necessary obtained via research and patenting activities (for a review on the limits of these indicators as proxies for innovation see Griliches, 1990), as earlier highlighted in the debate on development and catching-up achieved through social capabilities (Abramovitz, 1986), absorptive capacity (Cohen and 
Levinthal, 1990), technological capabilities (Kim, 1980, 1997), and more recently rejuvenated, among many others, in Archibugi and Coco (2005); Fagerberg, Shrolec, and Knell (2007); Fagerberg and Srholec (2008); and Fagerberg, Srholec; and Verspagen (2010).

On the other, when one moves from the national level to the regional level of analysis, these considerations become even more compelling because of the highly concentrated spatial profile of research activities (as widely documented for both the European and the U.S. cases; see among the many others Rodríguez-Pose and Crescenzi (2008) for Europe and Feldman (1994) for the U.S.) and the paramount importance of knowledge spillovers selectively diffusing across geographical (Jaffe, 1989; Jaffe et al., 1993; Moreno et al., 2005) and cognitive spaces (Breschi and Lissoni, 2009; Boschma, 2005; Capello and Caragliu, 2012). Since the contributions of Jaffe (1989) and Jaffe et al. (1993), the literature has in fact largely documented the importance of knowledge spillovers and has identified specific mechanisms directing knowledge flows such as localized specialized labor markets (Almeida and Kogut, 1999; Breschi and Lissoni, 2009), socioprofessional networks (Sing, 2005; Giuliani, 2007; Breschi and Lissoni, 2009), entrepreneurial dynamism (Armington and Acs, 2002; Acs and Armington, 2004, 2006; Storey and Acs, 2004; Acs and Varga, 2005; Fritsch and Falck, 2007), the structure of the local knowledge base and its specialization profile as summarized in the related variety debate (see among the many others Frenken, van Oort, and Verburg, 2007; Boschma and Iammarino, 2009), and the intensity and quality of university-industry relationship (Zucker, Darby, and Brewer, 1998; Varga, 2000 and 2009).

What can be grasped from the literature is that there is a wide consensus on the importance of some territorial preconditions to create knowledge and innovation and to turn them into growth; in general, it is given for granted that if a region produces knowledge, it is able to turn it into innovation. However, the literature implicitly provides explanations for a situation in which the local knowledge-innovation nexus does not hold, and innovation takes place without a strong formal local knowledge creation process; these explanations rest in the existence in some areas of informal knowledge and/or in knowledge spillovers processes from knowledge-intensive regions.

Moreover, in the literature the linkage between knowledge, innovation, and regional growth is indisputable. Our claim is that nothing in the literature suggests that, if we assume the existence of different innovation modes-based on formal knowledge, informal knowledge, or external knowledge-we have to expect these modes to have different growth benefits. This is something that is worth testing empirically, and it is the subject matter of the next sections.

\section{Testable Hypotheses}

Better to understand the knowledge-innovation-growth nexus at the regional level, this paper builds on the distinction between formal knowledge and innovation to assess their (spatially differentiated) impacts on regional growth. Similar efforts have been hampered to date by the paucity and/or low quality of innovation data (an especially major barrier in the European case: Hollanders, 2009), although with some exceptions for the U.S. case (Feldman, 1994; Anselin, Varga, and Acs, 1997; Varga, 2000; Acs, Anselin, and Varga, 2002). ${ }^{2}$

\footnotetext{
${ }^{2}$ In this regard, it is worth remarking that innovation data have been used in the frame of "innovation production function" and not to assess the impact of innovation on economic growth (Feldman, 1994; Anselin et al., 1997; Acs et al., 2002).
} 
By looking at the differentiated mix of knowledge and innovation across regions, this approach also emphasizes the importance of accounting for spatial heterogeneity in order to fully grasp the differentiated pathways from knowledge and innovation to higher economic performance (Varga, 2000, 2006; Capello and Lenzi, 2013a). In so doing, it departs from most previous studies on the impact of knowledge on regional growth, which have mostly focused on the "average impact for the average region," and it complements recent studies that propose differentiated impacts of formal knowledge on growth according to distinctions such as socioeconomic definitions (politically decided), for example, advanced versus disadvantaged regions defined as Objective $1^{3}$ regions (Sterlacchini, 2008; Charlot, Crescenzi, and Musolesi, 2012), or to institutional distinctions (e.g., EU15-non-EU15 regions), which ultimately capture different stages of socioeconomic development (Marrocu et al., 2013). However, these socioeconomic and institutional distinctions do not make it possible to capture important heterogeneity sources across regions in the types of knowledge needed for innovating and in the propensity toward innovation, which mostly depend upon specific and systemic context conditions and tend to be highly cumulative and persistent over time (Iammarino, 2005; Iammarino and McCann, 2006).

Besides confirming the importance of knowledge inputs (namely, the share of R\&D expenditures over GDP) and innovation as drivers of regional growth, as consistently shown in previous research, this paper aims to demonstrate that the growth advantages stemming from knowledge and innovation are spatially heterogeneous and do not always match.

To this end, the paper acknowledges the possibility that knowledge and innovation do not necessarily overlap at the spatial level so their effects are expected not to offset one another. The first hypothesis, then, posits that knowledge and innovation have statistically different effects on regional growth.

Second, while the link between (formal) knowledge intensity and regional growth on the one hand, and the link between (formal) knowledge intensity and innovation are on average indisputable, regions may be differently positioned and show different advantages in terms of formal knowledge creation potential and innovation creation potential, as innovation can derive from other sources than formal knowledge (namely, knowledge spillovers and informal knowledge), as thoroughly documented by the literature reviewed earlier. This suggests that the highly selective and concentrated spatial profile of formal knowledge and its effects on growth does not necessarily apply also to innovation. The second hypothesis then posits that the growth advantages stemming from formal knowledge are likely to be spatially more selective and concentrated than the growth advantages stemming from innovation.

Third, if one admits the fact that regions may be highly innovative by exploiting informal knowledge and knowledge spillovers and not exclusively by exploiting formal knowledge resources, formal knowledge and innovation not only may manifest with different intensities and penetration across space but also, and more interestingly, their interplay may have heterogeneous effect on GDP growth. As the debate on innovation and catching-up mentioned earlier suggests, especially in developing economies with limited technological and scientific bases, development trajectories rely more on learning, innovation, diffusion, if not proactive and creative imitation, than on the expansion of R\&D expenditures.

${ }^{3}$ Objective1 regions are regions with a per capita gross domestic product (GDP) lower than 75 percent of the European Union average. 
The third hypothesis, then, posits that the growth benefits accruing from innovation do not necessarily match the strength of the formal local knowledge base. In particular, innovation is expected to generate relatively higher growth advantages in regions with a relatively more limited formal knowledge base.

The next section develops the econometric regression framework to support these hypotheses empirically.

\section{THE EMPIRICAL FRAMEWORK}

\section{The Conceptual Logic}

The empirical model tested was designed to assess the importance of knowledge and innovation for regional growth while controlling for additional determinants of regional growth (i.e., those elements that enable a region to find a position in the international division of labor and maintain that position over time) suggested in the literature. Therefore, our empirical model has to explain regional growth by including:

(1) indicators capturing knowledge and innovation intensity;

(2) territorially embedded elements that facilitate their creation (i.e., socioeconomic local factors that enable knowledge and innovation to take place); and

(3) region's economic dynamics and development stage controls.

\section{(1) Knowledge and Innovation Intensity}

Consistently with the literature on regional growth and with endogenous growth theory (e.g., Crescenzi, 2005; Ertur and Koch, 2011; Marrocu et al., 2013), an indicator of formal and basic knowledge, measured through R\&D expenditures on GDP, was included in order to capture knowledge inputs. This was complemented with an indicator of informal knowledge embedded in human capital, labeled "capabilities," in order to control for different types of knowledge base locally available (Asheim and Coenen, 2005; Asheim and Hansen, 2009; Fagerberg and Srholec, 2008). Moreover, differently from previous studies (e.g., Acemoglu et al., 2006; Rodríguez-Pose and Crescenzi, 2008), innovation was distinguished from $R \& D$ expenditures, the expectation being that this variable has an additional explanatory power with respect to knowledge; this variable directly accounts for the impact of new products and/or processes introduced in the market on the GDP growth rate. Empirically, the presence of both R\&D expenditure and innovation may be problematic. First, because the R\&D variable includes both commercialized and noncommercialized knowledge, one cannot rule out that it already captures innovative efforts by firms. This possibility was excluded by checking for multicollinearity between knowledge and innovation. This turned out to be limited, since, as shown in the next sections, the introduction of the innovation variable added explanatory power to the regional growth model. Second, there may be not only a simultaneous effect of both R\&D and innovation on growth; it may also be the case that knowledge generates innovation, which leads to higher economic performance. This logical path would require a structural equation modeling approach; in this case, the results of such a modeling strategy turned out to be similar to those of the OLS model, showing that innovation has an impact on GDP growth regardless of the input that it receives from $R \& D .{ }^{4}$

\footnotetext{
${ }^{4}$ The results are available from the authors upon request.
} 


\section{(2) Knowledge and Innovation Territorial Enabling Factors}

Innovation is a territorially embedded process, and it cannot be fully understood independently of the social and institutional conditions (Rodríguez-Pose and Crescenzi, 2008). For this reason, the second group of variables considered in the empirical framework included socioeconomic local factors that make the presence of favorable systems of innovation more likely.

Several contributions from the milieu innovateur theory (Camagni 1991) to institutional economics (Tabellini, 2008) stress the importance of a cooperative and trustworthy economic environment for enhancing local knowledge creation, innovation, and more generally the business atmosphere and economic performance. For this reason, an indicator of social capital was introduced as a measure of trust, cooperative propensity, and collective actions within a region. Higher cooperation should promote knowledge and innovation circulation and socialization, thus enhancing local growth potentials.

An indicator for agglomeration economies was also added. This was meant to capture the synergic effects, complementarities, collective learning effects, and local knowledge spillovers arising in the dense agglomerations of economic activities at the base of knowledge and innovation creation, and local growth. ${ }^{5}$ The importance of agglomeration economies has in fact been consistently documented in the literature (see Beaudry and Schiffauerova, 2009, for a review) on innovative and regional performance, as well as in the NEG debate (Krugman, 1991); ceteris paribus, an agglomerated region grows more because of synergic effects and complementarities arising in densely populated areas.

Moreover, a control for value-added functional specialization was inserted, since the literature has widely debated its role as an element stimulating innovation (Beaudry and Schiffauerova, 2009). High-level functional specialization was captured as the share of upper-level occupations, with the expectation that upper-level occupations are more skill-intensive and more inclined to stimulate knowledge and innovation, and therefore the growth rate, than lower-level occupations (Duranton and Puga, 2000).

Furthermore, a measure of accessibility to the region was introduced, the expectation being that the greater the accessibility, the higher the probability of acquiring new knowledge, new ideas, and new information, and therefore the higher the growth rate. The role of accessibility and infrastructure has always been central in studies of regional growth, and it has been more recently relaunched in the NEG debate (Krugman, 1991).

Finally, an important element that can explain GDP growth is the presence of entrepreneurship (Parker, 2005). New businesses creation rate would be the best indicator to account for entrepreneurship. Differently from the U.S. case (see among the many others Armington and Acs, 2002; Acs and Armington, 2004, 2006; Storey and Acs, 2004; Acs and Varga, 2005), there is not a comparable indicator of entrepreneurship for the whole population of regions of the EU27 member states. More in general, entrepreneurship measurement is highly problematic in the European context and severely impaired by the availability of good indicators, self-employment being the most common indicator used in empirical research despite it being highly controversial and likely to provide

\footnotetext{
${ }^{5}$ This variable also makes it to control indirectly for the relevance of knowledge-intensive (business) services and creative industries in general, whose knowledge and innovative efforts might be underestimated by the present indicators for $R \& D$ and innovation. In fact, the location quotient of knowledgeintensive services is statistically significantly higher in denser and agglomerated regions with respect to the others.
} 
ambiguous results (IAREG 2010; Marrocu et al., 2013). ${ }^{6}$ Therefore, given data constraints, in the analysis reported here we calculated the regional share of self-employment on total employment, with the exclusion of the whole sale and retail sector, which tends to inflate this ratio.

\section{(3) Economic Dynamics and Socioeconomic Development Stage}

A last group of variables is necessary to control for a region's economic dynamism. In order to assess whether GDP growth was the outcome of employment or productivity increases, the dynamics of the regional labor market were taken into consideration and measured through an indicator of employment growth rate.

To control for a region's economic attractiveness and the relevance of trade (consistently with the literature on trade and integration theory, e.g., Grossman and Helpman, 1990; Badinger and Tondl, 2002), an indicator of foreign direct investments (FDIs) penetration rate was introduced. This was expected to affect the GDP growth rate positively, and it was supposed to generate a push effect on the local economy.

As originally highlighted by Perloff (1957) and Perloff et al. (1960), also the sectoral specialization of the regional economy can affect regional growth potentials through proportional mix and shift effects. Its inclusion was therefore important, also because it might explain the innovation capacity of a region regardless of its knowledge intensity. In fact, for example, knowledge-intensive services (KIS) and creative industries are highly dynamic sectors and can act as drivers of growth, even if R\&D expenditures in this sector are almost null (EC, 2012). Accordingly, the regional specialization in KIS was inserted.

Finally and consistently with the literature on regional growth and convergence (showing possible divergent club-like growth patterns [Ramajo et al., 2008]), two additional controls were added: a dummy variable for regions located in New Member States (NMS), which showed a remarkable distinctive growth behavior with respect to EU15 regions in the early-2000s (Capello et al., 2008) and structural funds expenditures in order to account for the likely positive impact of public expenditures aimed at stimulating growth in developing regions.

We acknowledge that this empirical framework might overlook specific elements that have been found to be closely correlated with regional growth. For example, the availability of financial resources like venture capital is certainly crucial for engaging in highly risky and costly activities such as research and innovation. Moreover, the availability of financial services such as venture capital shows a prominent tendency to cluster in space and an uneven distribution at the regional level. Similarly, the estimation framework would have benefited from the inclusion of an indicator of the presence of universities and research centers. However, the lack of consistent, comparable, and detailed data at the NUTS2 level for all EU countries prevented us from including these elements in the analysis. We tried to overcome the lack of these data by inserting a dummy variable, which captures the presence in the region of a dynamic large metropolitan area; this variable indirectly controls for the presence of financial capital, of universities, and research centers because both financial and higher education and research activities are prominently located in metropolitan settings.

Table 1 reports the description of the variables and their sources, and Table 2 their descriptive statistics. The correlation matrix is available in Appendix A.

\footnotetext{
${ }^{6}$ Self-employment may be in fact not only the outcome of innovation- and market-related opportunities but also of high unemployment and uncertain career prospects or, as largely in underdeveloped economies, of necessity (Buenstorf, 2009).
} 


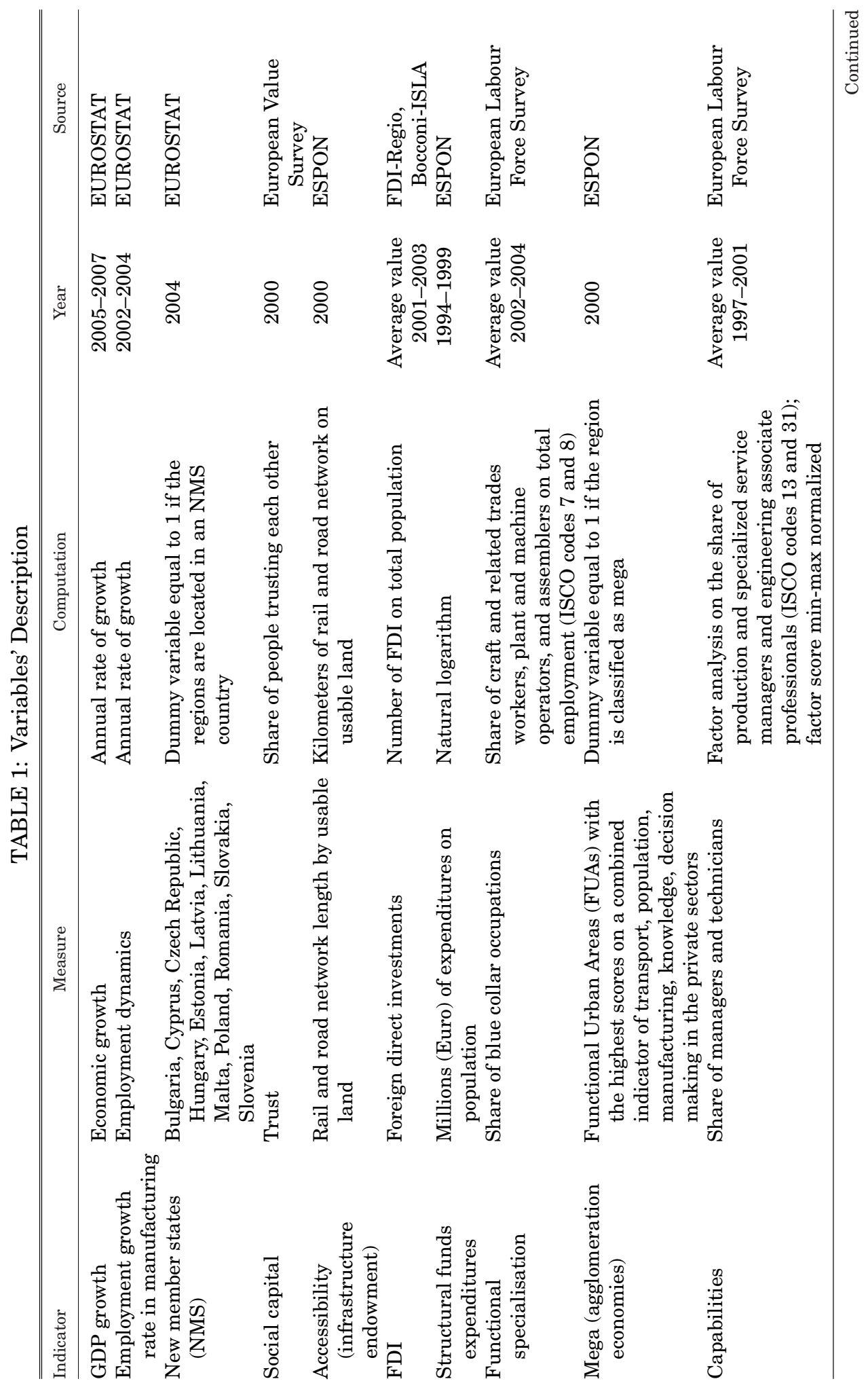




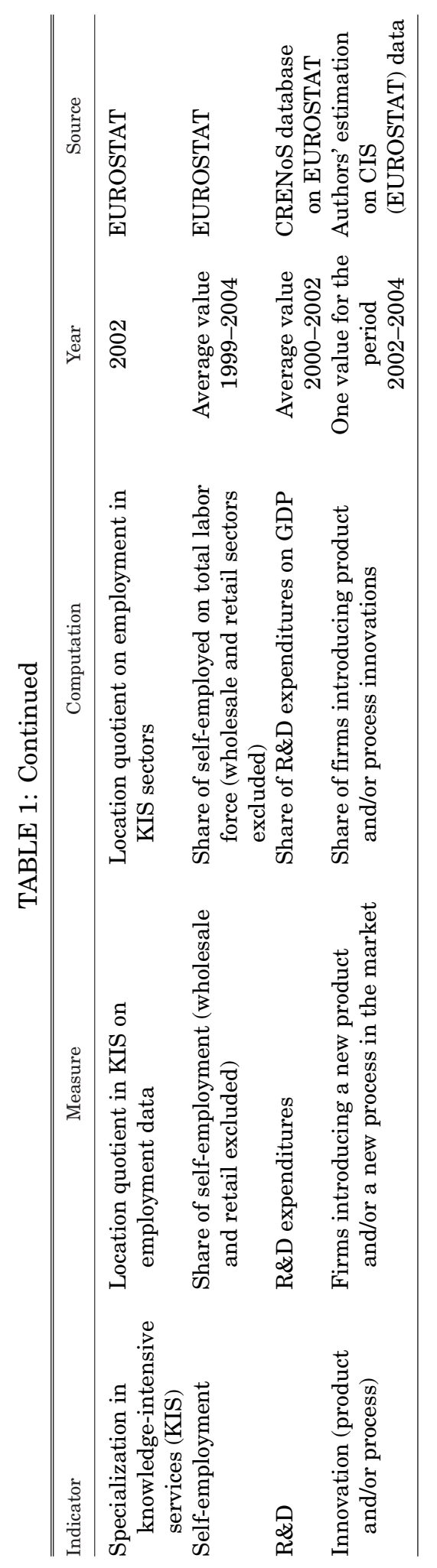


TABLE 2: Descriptive Statistics

\begin{tabular}{|c|c|c|c|c|c|}
\hline Variable & Obs. & Mean & Std. Dev. & Min. & Max. \\
\hline $\begin{array}{l}\text { GDP growth rate } \\
(2005-2007)\end{array}$ & 262 & 3.64 & 2.05 & -1.33 & 12.41 \\
\hline $\begin{array}{l}\text { Employment growth } \\
\text { rate in manufacturing } \\
(2002-2004)\end{array}$ & 262 & -2.01 & 3.41 & -21.32 & 13.41 \\
\hline Trust (2000) & 262 & 30.97 & 15.77 & 0 & 82 \\
\hline $\begin{array}{l}\text { Accessibility } \\
\text { (infrastructure } \\
\text { endowment) (2000) }\end{array}$ & 262 & 27.03 & 39.48 & 0 & 453.51 \\
\hline FDI (2003-2005) & 262 & 0.19 & 0.40 & 0 & 4.29 \\
\hline $\begin{array}{l}\text { Structural funds } \\
\text { expenditures } \\
\text { (1994-1999) }\end{array}$ & 262 & $33,454,030$ & $56,140,880$ & 0 & $434,866,600$ \\
\hline $\begin{array}{l}\text { Share of blue collar } \\
\text { occupations } \\
(2002-2004)\end{array}$ & 262 & 33.3 & 7.1 & 16.33 & 58.73 \\
\hline $\begin{array}{l}\text { Capabilities } \\
\quad(1997-2001)\end{array}$ & 262 & 0.40 & 0.16 & 0 & 1 \\
\hline LQ KIS (2002) & 262 & 1.02 & 0.30 & 0.32 & 2.01 \\
\hline $\begin{array}{l}\text { Self-employment } \\
\quad(1999-2004)\end{array}$ & 262 & 12.11 & 6.22 & 1.55 & 38.37 \\
\hline$R \& D(2000-2002)$ & 262 & 1.37 & 1.21 & 0.10 & 6.60 \\
\hline Innovation (2002-2004) & 262 & 35.54 & 13.27 & 7.97 & 87.10 \\
\hline
\end{tabular}

\section{The Model and the Estimation Procedure}

The model to be estimated was a regional growth model, made dependent on knowledge and innovation intensity, and controlled for the territorial enabling factors and the economic dynamics and socioeconomic development stage, as follows:

(1)

$$
\begin{aligned}
\Delta G D P_{r}= & \alpha_{0}+\beta_{1} \Delta \text { Empl }_{r}+\beta_{2} \text { NMS }_{r}+\beta_{3} \text { SocialCapital }_{r}+\beta_{4} \text { Infrastructure }_{r}+ \\
& +\beta_{5} \text { FDI }_{r}+\beta_{6} \text { StructuralFund }_{r}+\beta_{7} \text { Functional Specialization }_{r} \\
& +\beta_{8} \text { AgglomerationEconomies }_{r}+\beta_{9} \text { Capabilities }+\beta_{10} \text { R\&D } D_{r} \\
& +\beta_{11} \text { Innnovation }_{r}+\beta_{12} \text { Selfemployment }_{r}+\beta_{13} \text { SpecializationinKIS }_{r}+\varepsilon_{r},
\end{aligned}
$$

where $\triangle G D P_{r}$ is the regional annual GDP growth rate of regions in the period 2005-2007. ${ }^{7}$ Estimation of the model presented in (1) enabled to test the first and the second hypotheses elaborated in Section 2, that is, that knowledge and innovation have distinctive impacts

\footnotetext{
${ }^{7}$ The regional annual GDP growth rate has been computed in the years 2005-2007 to exclude possible cofounding effects due the explosion of the global financial crisis started in 2008 in Europe. Previous years could not be exploited because of simultaneity with the innovation variable. Still, better to understand the potential asynchronous business cycles effects across EU regions, we also modified the dependent variable and computed the regional annual GDP growth rate in the period 2005-2009. This new set of estimates, available upon request, provides interesting information on local assets affecting regional resilience to deep macroeconomic shocks. In particular, whereas the importance of local knowledge assets seems to vanish, innovation preserves its strategic relevance, despite with a reduced magnitude.
} 
on regional growth and do not offset one other and that the growth benefits stemming from innovation are spatially more diffused than that arising from R\&D.

To unravel the heterogeneity of knowledge and innovation impacts across regions, the $R \& D$ and innovation variables were interacted (2). The enlarged models to be estimated therefore became as follows:

$$
\begin{aligned}
\Delta G D P_{r}= & \alpha_{0}+\beta_{1} \Delta \text { Empl }_{r}+\beta_{2} \text { NMS }_{r}+\beta_{3} \text { SocialCapital }_{r}+\beta_{4} \text { Infrastructure }_{r}+ \\
& +\beta_{5} \text { FDI }_{r}+\beta_{6} \text { StructuralFund }_{r}+\beta_{7} \text { Functionsal Specialization }_{r} \\
& +\beta_{8} \text { Agglomerationeconomies }_{r}+\beta_{9} \text { Capabilities }+\beta_{10} \times R \& D_{r}+\beta_{11} \text { Innovation }_{r} \\
& +\beta_{12} \text { R\&D } D_{r} \times \text { Innovation }_{r}+\beta_{13} \text { Selfemployment }_{r}+\beta_{14} \text { SpecializationinKIS }_{r}+\varepsilon_{r} .
\end{aligned}
$$

Estimation of this model enabled to test the third hypothesis elaborated in Section 2, that is, that the growth advantages stemming from innovation do not always match the strength of the local formal knowledge base.

Moreover, controls for spatial dependency with appropriate econometric techniques (namely, spatial lag and spatial error models, indicated as SAR and SEM) were implemented when statistically relevant. As a final robustness check, 2SLS instrumental variable regressions were performed to control for endogeneity that might occur so as to boost our confidence in causal sequence. Importantly, the Durbin-Wu-Hausman test did not allow rejection of the null hypothesis that regressors are exogenous, suggesting that OLS estimates are preferable to 2SLS estimates. Still, results remained robust to this control, as described in Appendix B.

\section{Some Hints on the Knowledge-Innovation Nexus at the Regional Level}

Some interesting observations can be drawn in terms of knowledge and innovation patterns. As described in Table 1, we rely on two crucial indicators to capture the knowledge and innovation intensity of European regions. As to the former, we measure it as the share of R\&D expenditures (both private and public) on GDP (covering the 2000-2002 period), as is customary in the literature (see on the European case: Crescenzi, 2005; Rodríguez-Pose and Crescenzi, 2008; Sterlacchini, 2008; and on the U.S. case, among the many others Jaffe, 1989). As to the latter, innovation data have been compiled by the authors on the basis of data from the Community Innovation Survey (CIS) EUROSTAT database. In particular, these data are based on national CIS4 wave figures (covering the 2002-2004 period), next estimated at the NUTS2 level, ${ }^{8}$ and they capture the share of firms introducing product and/or process innovations in a region. Whereas innovation data on European regions have been quite recently used to develop a taxonomy of regional innovative performances (Hollanders et al., 2009), to the best of our knowledge, innovation data have not yet been used to explain regional growth potentials.

The Lisbon Agenda, reinforced by the Europe 2020 Strategy, has declared the importance of research and innovation to guarantee competitive and smart growth in Europe, and it has set a specific target for domestic R\&D expenditures, which should be increased to 3 percent of national GDP. As of 2002, R\&D spending on GDP in Europe exhibited a strong variation across regions, ranging from values lower than 0.5 percent to values of more than 6 percent (Figure 1). A very small number of regions

\footnotetext{
${ }^{8}$ The database on innovative firms at NUTS2 level is a novelty of this work. For an in-depth explanation of the estimation strategy, see Capello et al. (2012) and Capello and Lenzi (2013b).
} 


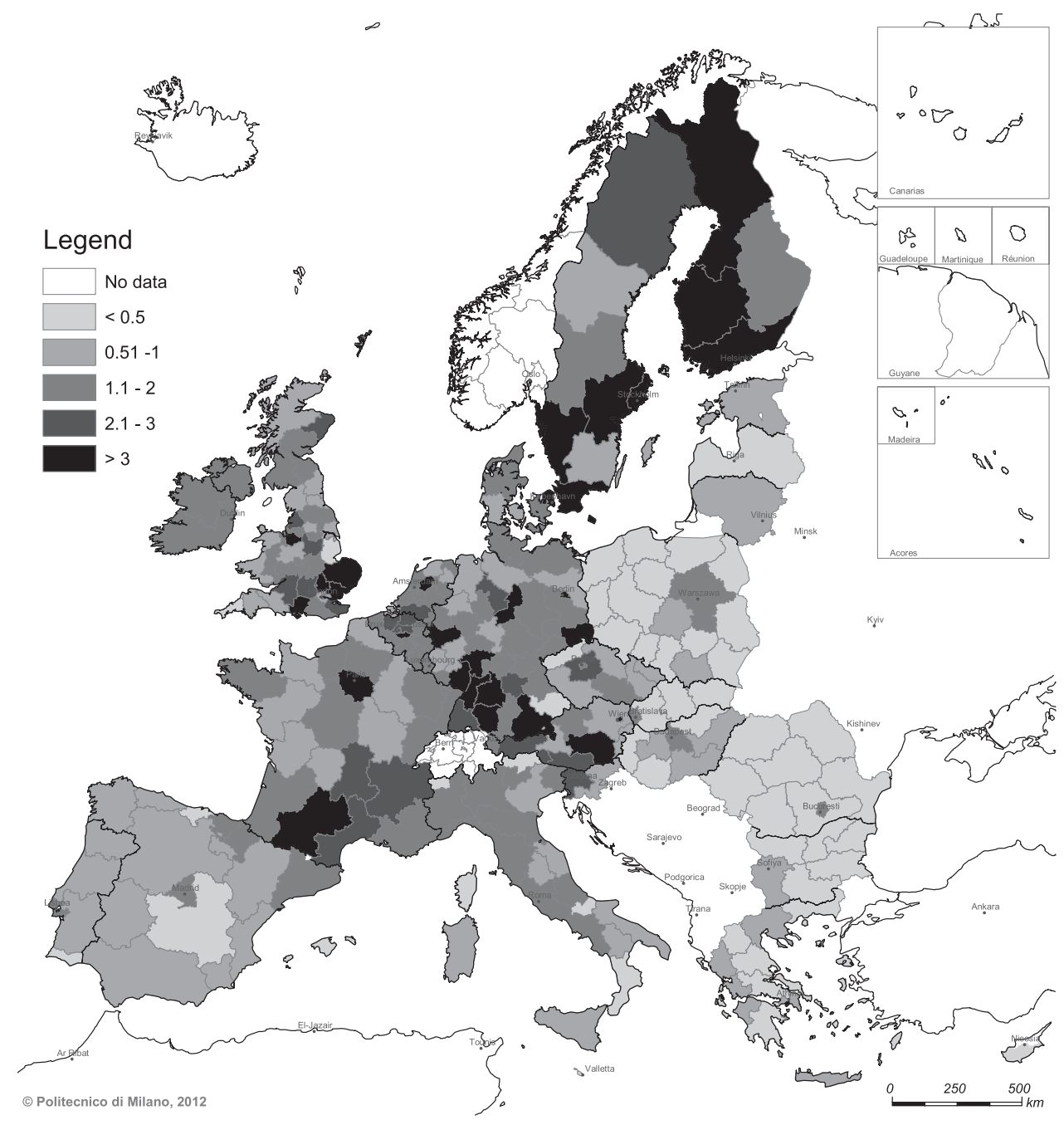

Source: Capello and Lenzi (2013b).

FIGURE 1: R\&D Expenditures on GDP (Average Value 2000-2002).

(i.e., 30 representing 12 percent of NUTS2 European regions) in Europe achieved (and exceeded) the 3 percent R\&D expenditures on GDP target, thus testifying that the achievement of this threshold at the regional level is still an ambitious goal. ${ }^{9}$ Moreover, its spatial distribution seems strongly concentrated: more R\&D-intensive regions are located in Scandinavian countries, the Southern U.K., and Central Europe, with the exception of the French region of Midi-Pyréneées. Eight European countries host

${ }^{9}$ These figures are highly persistent. Only two regions were able to exceed the 3 percent R\&D on GDP threshold in the period 2000-2007 (namely, the Dutch Noord-Brabant and North-Eastern Scotland in the U.K.) and a few regions lost this status (namely, the French Île de France, the Dutch Flevoland, the German Köln and Münster). On the other hand, the share of R\&D expenditures on GDP is lower than 1 percent in most regions (respectively, 130 regions out of 262 in the period 2000-2002, and 114 regions out of 262 in the period 2006-2007), attesting to a positive trend in the years 2000-2007. 


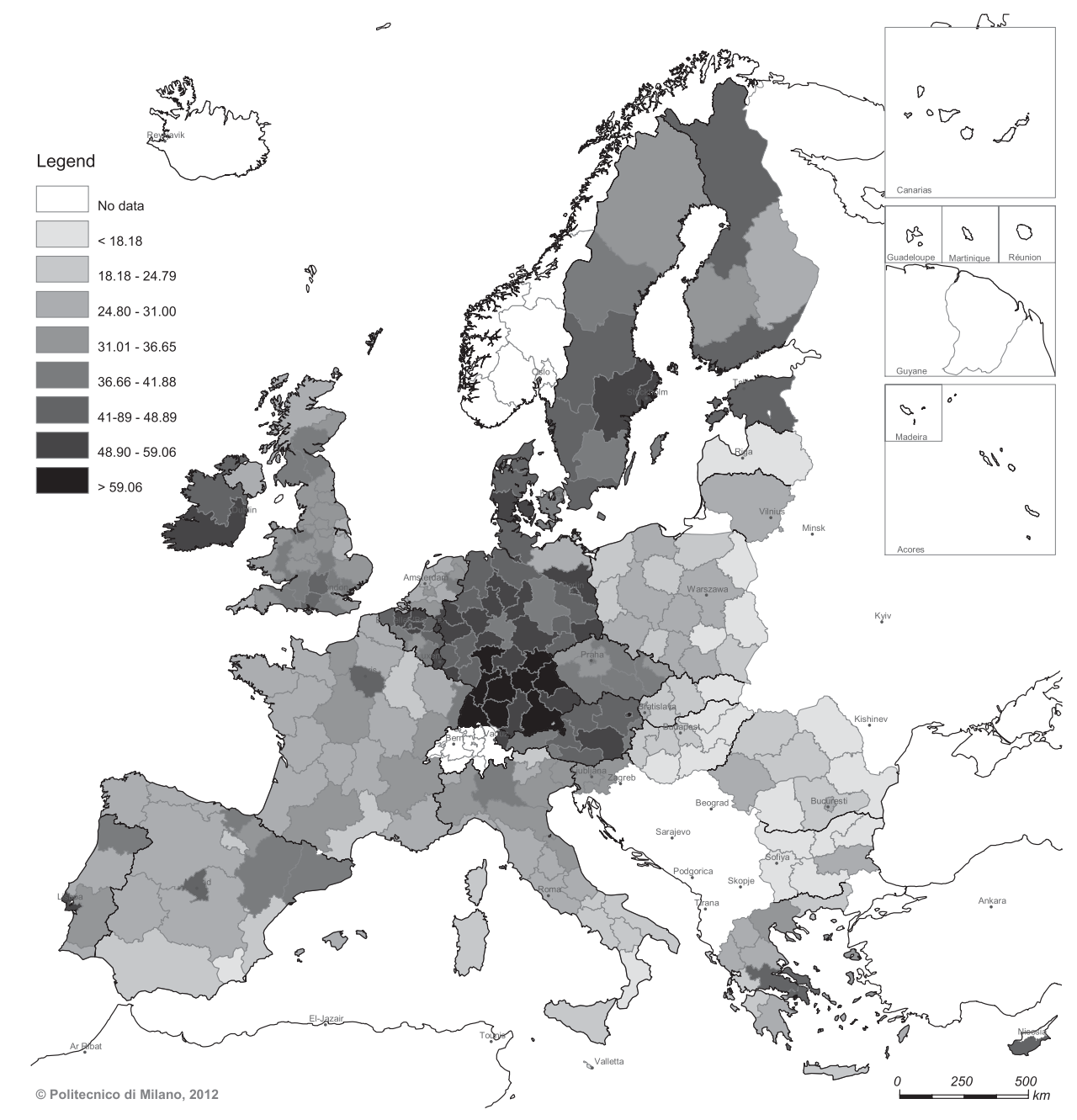

Source: Capello, Caragliu, and Lenzi (2012).

FIGURE 2: Share of Firms with Product and/or Process Innovation (2002-2004).

the most R\&D-intensive regions, namely Austria, Belgium, Germany, Denmark, Finland, France, The Netherlands, Sweden, and the U.K. Importantly, a very large number of regions belong to the lowest class, with R\&D on GDP lower than 0.5 percent. Last but not least, there is a clear East-West dichotomy: Eastern regions in fact show a capacity for R\&D spending which is much more limited than that of Western countries.

By contrast, the map displaying the share of firms with product and/or process innovations (Figure 2) is more scattered, and innovation patterns are more pervasive than R\&D expenditures on GDP. However, product and/or process innovation still display remarkable levels of concentration, with the bulk of innovative activities taking place in the strongest portion of Europe (Germany, the U.K. and Ireland, Scandinavian countries) with a few but relevant exceptions represented by some capital or metropolitan regions 
and single-region countries outside the core (Madrid, Lisbon, Île-de-France, Lombardy, Athens, Estonia, and Cyprus).

Importantly, comparison between the two maps (i.e., Figures 1 and 2) suggests that the ranking of R\&D expenditures on GDP and the ranking of the share of firms with product and/or process innovation do not always coincide. Although the correlation coefficient between R\&D and innovation is slightly above 0.5 (as shown in the correlation matrix in Appendix A), and statistically significant at conventional levels, there are several regions with innovation performances higher than the European average but R\&D expenditures lower than the European average, or the other way round, that is, formal knowledge and innovation do not always match at the regional level.

\section{THE KNOWLEDGE-INNOVATION NEXUS AT THE EMPIRICAL LEVEL}

Table 3 reports the estimates of (1) and (2). ${ }^{10}$ The results for the variables capturing knowledge and innovation territorial enabling factors and the variables capturing the region's economic dynamism, as well as those for the nature and pattern of development, are overall statistically significant and with the expected sign.

In particular, as regards a region's economic dynamism, GDP growth positively reacts to the FDI penetration rate, relatively more weakly to structural funds expenditures, and it is higher in Eastern European regions. Among all possible employment growth measures, only the manufacturing employment growth rate turned out to be significant.

As regards socioeconomic local enablers of knowledge and innovation, GDP growth is positively influenced by the synergic effects deriving from agglomeration economies, by trust and social capital, and by informal knowledge embedded in technical and managerial competences. On the other hand, GDP growth is moderately (but not significantly) hampered by a region's functional specialization in lower-level functions (i.e., blue-collar occupations) and, more significantly, by the accessibility level, suggesting that density and congestion effects prevail. Unfortunately, the self-employment variable does not turn out to be significant; this result may be due to an inadequate proxy to capture the actual impact of entrepreneurship and industrial dynamics on regional growth, which is unfortunately the only one available.

More interestingly, our results indicate that both knowledge and innovation play a crucial role in explaining growth patterns in European regions, thus supporting the efforts to enlarge and strengthen the European knowledge base proposed in the Lisbon agenda and relaunched by the Europe 2020 strategy. However, our findings also highlight a greater heterogeneity across European regions in the way regions exploit knowledge and innovation for growing. In what follows, we comment on our results in relation to each of the hypotheses formulated in Section 2 in turn.

\section{Hypothesis 1: The importance of knowledge and innovation for growth.}

Increasing the average R\&D spending at the EU level is certainly beneficial for achieving superior GDP growth rates, also after controlling for spatial interdependencies across regions (Table 3, Model 1). By computing GDP growth rate elasticity to $R \& D,{ }^{11}$ on average, a 1 percentage point increase in $R \& D$ spending yields a 0.15 percent increase in

\footnotetext{
${ }^{10}$ For reasons of space, we report only estimates based on SAR/SEM. Following Anselin (1988), we used Lagrange multiplier tests to decide on the model specification, that is, SAR versus SEM. OLS are available from the authors upon request.

${ }^{11}$ The regional elasticity of GDP growth rate to $R \& D\left(\mathrm{E}_{\mathrm{GDP} \text { gr,R\&D }}\right)$ is obtained by multiplying the R\&D estimated coefficient ( $\left.\beta_{R \& D, E U}\right)$ by the ratio between the EU average R\&D level and the EU average GDP growth rate, as the formula below summarizes: $\mathrm{E}_{\mathrm{GDP} \_ \text {gr,R\&D }}=\beta_{\mathrm{R} \& \mathrm{D}, \mathrm{EU}} \times\left(\mathrm{R}_{\mathrm{EUU}} / \mathrm{GDP}_{-} \mathrm{gr}_{\mathrm{EU}}\right)$
} 
TABLE 3: Determinants of Regional GDP Growth Rate (2005-2007)

\begin{tabular}{|c|c|c|c|c|c|c|}
\hline $\begin{array}{l}\text { Dependent Variable } \\
\text { GDP growth rate (2005-2007) }\end{array}$ & $\begin{array}{c}(1) \\
\text { SEM }\end{array}$ & $\begin{array}{l}(2) \\
\text { SAR }\end{array}$ & $\begin{array}{c}(3) \\
\text { SEM }\end{array}$ & $\begin{array}{l}(4) \\
\text { SAR }\end{array}$ & $\begin{array}{c}(5) \\
\text { SEM }\end{array}$ & $\begin{array}{l}(6) \\
\mathrm{LAG}\end{array}$ \\
\hline \multirow[t]{2}{*}{ NMS } & $0.049^{* * * *}$ & $0.049^{* * * *}$ & $0.058^{* * * *}$ & $0.051^{* * * *}$ & $0.062^{* * * *}$ & $0.045^{\text {***** }}$ \\
\hline & $(0.019)$ & $(0.019)$ & $(0.020)$ & $(0.019)$ & $(0.020)$ & $(0.018)$ \\
\hline \multirow[t]{2}{*}{ Trust (2000) } & $0.016^{\text {**** }}$ & $0.017^{* *}$ & $0.018^{* * *}$ & $0.017^{\text {*** }}$ & $0.018^{* *}$ & $0.015^{*}$ \\
\hline & $(0.009)$ & $(0.008)$ & $(0.009)$ & $(0.008)$ & $(0.009)$ & $(0.008)$ \\
\hline \multirow{2}{*}{$\begin{array}{l}\text { Employment growth rate in } \\
\text { manufacturing }(2002-2004)\end{array}$} & $0.069^{* *}$ & $0.053^{*}$ & $0.061^{* *}$ & $0.055^{*}$ & $0.067^{* *}$ & $0.062^{* *}$ \\
\hline & $(0.032)$ & $(0.032)$ & $(0.032)$ & $(0.031)$ & $(0.032)$ & $(0.031)$ \\
\hline \multirow{2}{*}{$\begin{array}{l}\text { Accessibility (infrastructure } \\
\text { endowment) (2000) }\end{array}$} & $-0.006^{* * *}$ & $-0.006^{* *}$ & $-0.007^{* *}$ & $-0.006^{* *}$ & $-0.006^{* *}$ & $-0.006^{* *}$ \\
\hline & $(0.003)$ & $(0.003)$ & $(0.003)$ & $(0.003)$ & $(0.003)$ & $(0.003)$ \\
\hline \multirow[t]{2}{*}{ FDI (2001-2003) } & $0.009^{* * * *}$ & $0.005^{* *}$ & $0.008^{* * *}$ & $0.005^{* *}$ & $0.009^{* * *}$ & $0.006^{* *}$ \\
\hline & $(0.003)$ & $(0.003)$ & $(0.003)$ & $(0.003)$ & $(0.003)$ & $(0.003)$ \\
\hline \multirow{2}{*}{$\begin{array}{l}\text { Structural funds expenditures } \\
\quad(1994-1999)\end{array}$} & 0.002 & 0.001 & 0.002 & 0.001 & $0.002^{*}$ & 0.001 \\
\hline & $(0.001)$ & $(0.001)$ & $(0.001)$ & $(0.001)$ & $(0.001)$ & $(0.001)$ \\
\hline \multirow{2}{*}{$\begin{array}{l}\text { Share of blue collar occupations } \\
\quad(2002-2004)\end{array}$} & -0.012 & -0.034 & -0.028 & -0.028 & -0.016 & -0.023 \\
\hline & $(0.029)$ & $(0.026)$ & $(0.028)$ & $(0.026)$ & $(0.028)$ & $(0.026)$ \\
\hline \multirow[t]{2}{*}{ Mega (2000) } & $0.007^{* * * *}$ & $0.006^{* * * *}$ & $0.007^{* * * *}$ & $0.005^{* *}$ & $0.007^{* * * *}$ & $0.006^{* *}$ \\
\hline & $(0.002)$ & $(0.002)$ & $(0.003)$ & $(0.002)$ & $(0.003)$ & $(0.002)$ \\
\hline \multirow[t]{2}{*}{ Capabilities (1997-2001) } & $0.036^{\text {**** }}$ & $0.030^{* * * *}$ & $0.032^{\text {***** }}$ & $0.031^{* * * *}$ & $0.036^{* * * *}$ & $0.030^{* * * *}$ \\
\hline & $(0.010)$ & $(0.008)$ & $(0.010)$ & $(0.008)$ & $(0.010)$ & $(0.008)$ \\
\hline \multirow[t]{2}{*}{ LQ KIS (2000) } & -0.014 & -0.003 & -0.009 & -0.004 & -0.011 & -0.005 \\
\hline & $(0.009)$ & $(0.008)$ & $(0.009)$ & $(0.008)$ & $(0.009)$ & $(0.007)$ \\
\hline \multirow[t]{2}{*}{ Self-employment (1999-2004) } & 0.026 & 0.011 & 0.026 & 0.013 & 0.032 & 0.026 \\
\hline & $(0.029)$ & $(0.027)$ & $(0.029)$ & $(0.027)$ & $(0.028)$ & $(0.027)$ \\
\hline \multirow[t]{2}{*}{ R\&D (2000-2002) } & $0.349^{* * * *}$ & & & $0.220^{* *}$ & $0.274^{* * * *}$ & $0.951^{* * *}$ \\
\hline & $(0.100)$ & & & $(0.106)$ & $(0.105)$ & $(0.284)$ \\
\hline \multirow[t]{2}{*}{ Innovation (2002-2004) } & & $0.040^{\text {**** }}$ & $0.036^{* * * *}$ & $0.034^{* * * *}$ & $0.026^{* *}$ & $0.062^{* * * *}$ \\
\hline & & $(0.010)$ & $(0.011)$ & $(0.011)$ & $(0.011)$ & $(0.015)-$ \\
\hline \multirow[t]{2}{*}{$\mathrm{R} \& \mathrm{D} \times$ Innovation } & & & & & & $1.676^{* * *}$ \\
\hline & & & & & & $(0.604)$ \\
\hline \multirow[t]{2}{*}{ Constant } & 0.000 & -0.014 & -0.010 & -0.017 & -0.018 & -0.024 \\
\hline & $(0.025)$ & $(0.022)$ & $(0.025)$ & $(0.022)$ & $(0.025)$ & $(0.21)$ \\
\hline Lagrange multiplier (error lag) & $14.446^{* * *}$ & $2.857^{*}$ & $2.857^{*}$ & $3.968^{* *}$ & $3.968^{* * *}$ & 1.944 \\
\hline $\begin{array}{l}\text { Robust Lagrange multiplier (spatial } \\
\text { error) }\end{array}$ & $6.366^{* * *}$ & 0.592 & 0.592 & 1.401 & 1.401 & 0.050 \\
\hline Lagrange multiplier (spatial lag) & $8.202^{* * * *}$ & $2.809^{*}$ & $2.809^{*}$ & $2.796^{*}$ & $2.796^{*}$ & $3.419^{*}$ \\
\hline $\begin{array}{l}\text { Robust Lagrange multiplier (spatial } \\
\text { lag) }\end{array}$ & .122 & .544 & .544 & .229 & 0.229 & 1.526 \\
\hline \multirow[t]{2}{*}{ Lambda (SEM)/Rho (SAR) } & $0.756^{* * *}$ & $0.254^{*}$ & $0.617^{* * * *}$ & $0.253^{*}$ & $0.686^{* * * *}$ & $0.272^{*}$ \\
\hline & $(0.115)$ & $(0.154)$ & $(0.181)$ & $(0.153)$ & $(0.151)$ & $(0.151)$ \\
\hline Sq. Corr. & 0.35 & 0.42 & 0.39 & 0.43 & 0.39 & 0.45 \\
\hline Observations & 262 & 262 & 262 & 262 & 262 & 262 \\
\hline
\end{tabular}

Note: SEM and SAR estimates are based on a row-standardized continuous distance matrix; the diagonal elements are set at zero whereas the off-diagonal elements represent the distance between centroids of each pairs of regions.

$* P<0.10, * * P<0.05, * * * P<0.01$.

Robust standard errors in parentheses. OLS estimates available upon request. 
TABLE 4: Elasticity of GDP Growth to R\&D in EU and at Different Quartile Values of $\mathrm{R} \& \mathrm{D}$

\begin{tabular}{lc}
\hline \hline & Elasticity of GDP Growth to R\&D (EGDP_gr,R\&D) \\
\hline EU average & 0.15 \\
R\&D $=$ 1st quartile & 0.04 \\
R\&D $=$ 2nd quartile & 0.08 \\
R\&D = 3rd quartile & 0.15 \\
R\&D $=$ 4th quartile & 0.34 \\
\hline
\end{tabular}

Note: Elasticity values are computed according to the estimated coefficients reported in Table 3, model 1.

the GDP growth rate (Table 4). This result is therefore largely consistent with previous findings in the literature and confirms that knowledge is a crucial ingredient for faster regional growth.

Similarly, increasing innovation at the EU level has a positive effect on GDP growth rates, also after controlling for spatial interdependencies across regions (Table 3, Models 2 and 3 . By computing GDP growth rate elasticity to innovation, ${ }^{12}$ on average, a 1 percentage point increase in innovation yields a 0.35 percent increase in the GDP growth rate, a more than double elasticity than that of $R \& D$ (Table 6).

By jointly introducing R\&D and innovation as explanatory variables (Table 3 , Models 4 and 5), the results show that they both retain their significance and explanatory power. Given their relatively high correlation (more than 0.5 ), both R\&D and innovation coefficients are lower (and so their elasticity). However, especially R\&D is penalized because the magnitude of its coefficient almost halves and its significance shrinks from 1 percent to 10 percent, whereas innovation preserves its significance albeit with a smaller reduction of the magnitude of its coefficient. This suggests that innovation is likely to have greater explanatory power than knowledge, possibly because of its larger variance and spatial dispersion. ${ }^{13}$

Importantly, $\mathrm{chi}^{2}$ tests (implemented on Model 5) did not allow acceptance of the null hypothesis that the effect of innovation and $R \& D$ are jointly equal to zero $\left(\mathrm{chi}^{2}=20.89\right.$, $P<0.001)$ and that their coefficients are equal $\left(\mathrm{chi}^{2}=2.87, P<0.10\right)$. This once again highlights the importance of both variables in a regional growth model, and it supports our first hypothesis: that knowledge and innovation have considerable effects on their own. As highlighted by the descriptive analysis (Figures 1 and 2), they do not necessarily overlap in space and their effects do not offset one another.

\section{Hypothesis 2: $R \& D$ growth advantages are spatially more selective than innovation growth advantages.}

Further, to explore the heterogeneity and selectivity across space in the use of knowledge and innovation for growth, we computed the elasticity of GDP growth rate to R\&D and innovation at different quartile values of $R \& D$ and innovation, and assessed their statistical difference by means of pairwise $t$-tests (Tables 4-7).

\footnotetext{
${ }^{12}$ The regional elasticity of GDP growth rate to innovation ( $\mathrm{E}_{\mathrm{GDP} \text { gr.Innovation }}$ ) is obtained by multiplying the innovation estimated coefficient ( $\left.\beta_{\text {Innovation,EU }}\right)$ by the ratio between the EU average innovation level and the EU average GDP growth rate, as the formula below summarizes: E ${ }_{\mathrm{GDP}}$ gr.Innovation $=$ $\beta_{\text {Innovation,EU }} \times\left(\right.$ Innovation $\left.\left.\mathrm{EU} / \mathrm{GDP} \_\mathrm{gr}_{\mathrm{EU}}\right)\right]$

${ }^{13}$ Because the $R \& D$ variable includes both private and public expenditures, one cannot exclude that the innovation variable partly captures the R\&D efforts of innovative firms.
} 
TABLE 5: Pairwise $t$-Tests on the Difference between the Elasticity Values of GDP Growth to R\&D by R\&D Quartiles

\begin{tabular}{lcccc}
\hline \hline & 1st Quartile & 2nd Quartile & 3rd Quartile & 4th Quartile \\
\hline $\mathrm{R} \& \mathrm{D}=$ 1st quartile & - & & & \\
$\mathrm{R} \& \mathrm{D}=$ 2nd quartile & $<^{* * * *}$ & - & & \\
$\mathrm{R} \& \mathrm{D}=$ 3rd quartile & $<^{* * * * * * * *}$ & $<^{* * * * *}$ & - & - \\
$\mathrm{R} \& \mathrm{D}=$ 4th quartile & $<^{* * * * * *}$ & $<^{* * *}$ & $<^{* * *}$ & - \\
\hline
\end{tabular}

Note: n.s. $=$ not statistically significant.

${ }^{*} P<0.10,{ }^{* *} P<0.05,{ }^{* * *} P<0.01$.

TABLE 6: Elasticity of GDP Growth to Innovation in EU and at Different Quartile Values of Innovation

\begin{tabular}{lc}
\hline \hline & Elasticity of GDP Growth to Innovation (EGDP_gr,inno) \\
\hline EU average & 0.35 \\
Innovation $=$ 1st quartile & 0.21 \\
Innovation $=$ 2nd quartile & 0.27 \\
Innovation $=$ 3rd quartile & 0.46 \\
Innovation $=$ 4th quartile & 0.47 \\
\hline
\end{tabular}

Note: Elasticity values are computed according to the estimated coefficients reported in Table 3, model 5.

TABLE 7: Pairwise $t$-Tests on the Difference between the Elasticity Values of GDP Growth to Innovation by Innovation Quartiles

\begin{tabular}{lcccc}
\hline \hline & 1st Quartile & 2nd Quartile & 3rd Quartile & 4th Quartile \\
\hline Innovation = 1st quartile & - & & \\
Innovation = 2nd quartile & $<^{* *}$ & - & \\
Innovation = 3rd quartile & $<^{* * *}$ & $<^{* * * *}$ & - & - \\
Innovation = 4th quartile & $<^{* * *}$ & $<^{* * *}$ & n.s. & - \\
\hline
\end{tabular}

Note: n.s. $=$ not statistically significant.

${ }^{*} P<0.10,{ }^{* *} P<0.05,{ }^{* * *} P<0.01$.

Much information emerges from these tables that deserves additional explanation. First and quite interestingly, both R\&D and innovation appear to show some sort of scale advantages and require a certain critical mass in order to achieve their maximum potential. However, some interesting differences stand out. By looking at GDP growth elasticity to R\&D, the comparison of values in the bottom and top quartiles show sharp disparities (Table 4). Differences in GDP elasticity to R\&D across the R\&D distribution quartiles are all statistically significant suggesting a markedly spatially concentrated and selective distribution of R\&D growth benefits (Table 5). By moving from the first to the third and fourth quartile of R\&D, the elasticity of GDP growth to R\&D is almost four and ten times greater, respectively. The growth benefits accruing from R\&D are highly selective in space and subject to agglomeration effects, consistently with early observations by Varga (2000) on the relationship between R\&D public expenditures and innovation. Further investments in new formal knowledge creation do not generate the same positive effects on growth in all regions and regions showing greater R\&D spending seem to be better equipped to obtain the greatest advantages from its expansion. 


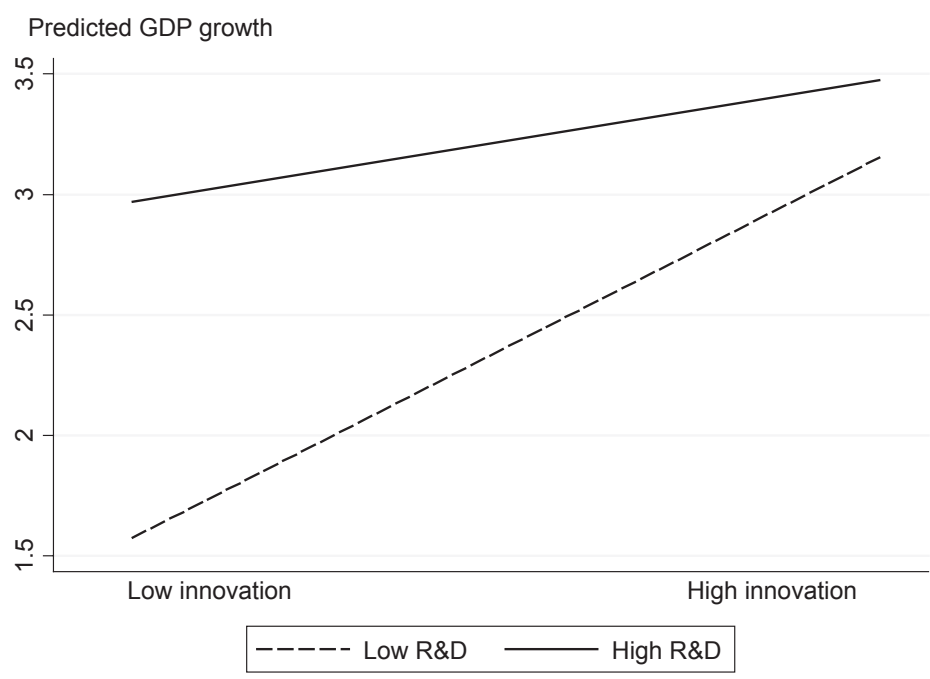

FIGURE 3: Marginal Effect of Innovation on GDP Growth Rate at Different Levels of R\&D (Interaction Effect between Innovation and R\&D).

By contrast, Table 6 shows that the elasticity of GDP growth to innovation is more evenly distributed in the different quartiles of the innovation variable distribution: by moving from the first to the fourth quartile of the innovation variable distribution, the elasticity of GDP growth to innovation is barely double. Overall, the differences in the elasticity of GDP growth rate to innovation are smoother (albeit they are statistically significant), signaling that innovation advantages are more distributed in space than R\&D advantages.

Therefore, the effects of innovation on GDP growth rate appear to be not only of larger magnitude but also, and more importantly, spatially more distributed than those stemming from formal knowledge, thus supporting Hypothesis 2.

Hypothesis 3: The growth advantages stemming from innovation do not always match the strength of the formal knowledge base.

The ways in which knowledge and innovation impact on regional growth, however, manifest with different intensities across European regions. To gain better understanding of the spatial heterogeneity in GDP growth rate responses to R\&D spending and innovation and their interplay, we interacted $R \& D$ and innovation variables (Table 3, Model 6) and computed the impact of innovation on GDP growth rate at a different level of R\&D expenditures (Figure 3).

Results from Table 3 indicate a significant negative sign for the interaction variable, supporting the idea of a substitution effect between R\&D and innovation. Figure 3 clarifies further this point. The "low $R \& D$ " line shows the slope of the effect of innovation on GDP growth rate when $R \& D$ is set at the one standard deviation point below its mean value; the "high $R \& D$ " line illustrates the same effect when $R \& D$ is set at the one standard deviation point above its mean value. The end points of each line are calculated by setting innovation, respectively, at one standard deviation point below its mean value and at one standard deviation point above its mean value. Figure 3 shows two interesting results. First, and consistent with the literature, GDP growth rate is systematically higher in more knowledge-intensive regions. However, and more interestingly, the impact of innovation on GDP growth sharply increases at low value of $R \& D$, that is, in regions with a limited 
TABLE 8: Capabilities and Knowledge Spillovers Values at Different R\&D Quartile Values

\begin{tabular}{lcc}
\hline \hline & Capabilities & Knowledge Spillovers \\
\hline EU average & 0.40 & 0.41 \\
$\mathrm{R} \& \mathrm{D}=$ 1st quartile & 0.47 & 0.52 \\
$\mathrm{R} \& \mathrm{D}=$ 2nd quartile & 0.44 & 0.39 \\
$\mathrm{R} \& \mathrm{D}=$ 3rd quartile & 0.37 & 0.34 \\
$\mathrm{R} \& \mathrm{D}=$ 4th quartile & 0.33 & 0.34 \\
\hline
\end{tabular}

R\&D intensity, whereas the impact of innovation on GDP growth remains relatively more stable at high level of $R \& D$, that is, in more R\&D- and formal knowledge-intensive regions. In fact, an increase in innovation at low levels of $R \& D$ allows to double GDP growth rate, whereas an increase in innovation at high levels of R\&D yields only a 7 percent increase in GDP growth rate. This result therefore supports our Hypothesis 3 that the growth benefits accruing from innovation do not always match the strength of the formal knowledge base: regions innovating in the absence of a strong local knowledge base can be as successful as more knowledge-intensive regions in turning innovation into a higher growth rate.

\section{INFORMAL KNOWLEDGE AND KNOWLEDGE SPILLOVERS AS CONDUIT FOR INNOVATION AND GROWTH}

These findings however raise the intriguing question of how regions can achieve innovation and exploit it for growing when lacking local sources of formal knowledge. As discussed in Section 2, the literature suggests that informal knowledge and knowledge spillovers can represent important, if not the main, ingredients for innovative activities especially in absence of endogenous formal knowledge creation capabilities, as it is frequently the case in developing economies. As supporting evidence of this "substitutability" effect between different types of knowledge sources, Table 8 presents the value of two indicators of capabilities and knowledge spillovers at different quartile values of the R\&D variable distribution.

The capabilities indicator is the one presented in Table 1 and accounts for knowledge embedded in technical and managerial competencies.

The spillover indicator captures the potential benefits that may accrue to each region $i$ from the pool of knowledge developed by other regions (i.e., knowledge potential), and it is computed as the sum of the R\&D expenditures on GDP in all the $N-i$ regions weighted by a measure of cognitive proximity between each pair of regions. In fact, the flows of basic knowledge are influenced to a limited extent by gravity-type behaviors, proxied by geographical proximity, and much more by similar backgrounds, cognitive maps, and common basic knowledge shared by two regions (Boschma, 2005; Breschi and Lissoni, 2009; Capello, 2009). For this reason, the potential acquisition of knowledge from other regions was weighted by the degree of cognitive proximity between pairs of regions. Cognitive proximity within a region was defined in terms of related variety, that is, the presence of complementary knowledge within a set of shared and common knowledge (Boschma, 2005; Basile, Capello, and Caragliu, 2012). This idea was transferred to the interregional level, and it was measured as the interregional knowledge similarity in a specific technological macrofield $i$ multiplied by the interregional knowledge variety in the technological subfields of macrofield $i$ among each pair of regions, as summarized in 
TABLE 9: Pairwise $t$-Tests on the Difference between Capabilities by R\&D Quartiles

\begin{tabular}{lcccc}
\hline \hline & 1st Quartile & 2nd Quartile & 3rd Quartile & 4th Quartile \\
\hline $\mathrm{R} \& \mathrm{D}=$ 1st quartile & - & & \\
$\mathrm{R} \& \mathrm{D}=$ 2nd quartile & n.s. & - & \\
$\mathrm{R} \& \mathrm{D}=$ 3rd quartile & $<^{* * * *}$ & $<^{* * *}$ & - \\
$\mathrm{R} \& \mathrm{D}=$ 4th quartile & $<^{* * *}$ & $<^{* * *}$ & $<^{* *}$ & - \\
\hline
\end{tabular}

Note: n.s. $=$ not statistically significant.

$* P<0.10, * * P<0.05, * * * P<0.01$.

TABLE 10: Pairwise $t$-Tests on the Difference between Knowledge Spillovers by R\&D Quartiles

\begin{tabular}{lcccc}
\hline \hline & 1st Quartile & 2nd Quartile & 3rd Quartile & 4th Quartile \\
\hline $\mathrm{R} \& \mathrm{D}=$ 1st quartile & - & & \\
$\mathrm{R} \& \mathrm{D}=$ 2nd quartile & $<^{* * * *}$ & - & - \\
$\mathrm{R} \& \mathrm{D}=$ 3rd quartile & $<^{* * *}$ & $<^{* * * *}$ & n.s. & - \\
$\mathrm{R} \& \mathrm{D}=$ 4th quartile & $<^{* * *}$ & $<^{* * * *}$ & \\
\hline
\end{tabular}

Note: n.s. $=$ not statistically significant.

$* P<0.10,{ }^{*} P<0.05,{ }^{* * *} P<0.01$.

the following formula: ${ }^{14}$

(3)

$$
\text { Cross - regional cognitive proximity }=\sqrt{\sum_{d 1=1}^{n}\left[\frac{\left(p_{i d 1} \times p_{j d 1}\right)}{\left(\mid p_{i d 1}-p_{j d 1 \mid}\right)} \times\left(\sum_{d 2=1}^{m}\left(\left|p_{i d 2}-p_{j d 2}\right|\right)\right)\right]},
$$

where $n$ represents the number of one-digit technological classes, $m$ the number of twodigit technological subclasses within each $n$ digit-1 class, $p_{i d 2}$ the share of region $i$ 's patents in digit-2 subclass $d 2, p_{j d 2}$ share of region $j$ 's patents in digit- 2 subclass $d 2, p_{i d 1}$ the share of region $i$ 's patents in digit- 1 class $d 1, p_{j d 1}$ share of region $j$ 's patents in digit- 1 class $d 1 .{ }^{15}$

Table 8 indicates that capabilities and knowledge spillovers are considerably higher in less R\&D-intensive regions and, significantly so, as pairwise $t$-tests in Tables 9 and 10 show. This evidence supports the conjecture that these alternative knowledge sources can represent a reasonable and sufficient base for endogenous innovative activities at the local level.

In conclusion, formal knowledge intensity per se is not a universal predictor of higher economic growth for all types of regions but it seems to be so only for a relatively smaller group of regions. These results therefore strongly enter the current policy debate on how to make Europe become a knowledge-based economy and achieve smart growth, as discussed in the next section.

\section{CONCLUSIONS: POLICY IMPLICATIONS}

Interesting policy implications can be drawn from this empirical analysis. The results do not gainsay the importance of R\&D activities for regional growth, and therefore the

\footnotetext{
${ }^{14}$ Because of the high skewness of the distribution of this variable, data were transformed using a square root transformation, a methodology largely applied in the literature (Hollanders et al., 2009).

${ }^{15} \mathrm{~A}$ richer discussion of this indicator is available in Capello and Caragliu (2012).
} 
correctness of Europe 2020's focus on a "smart growth" based on knowledge and innovation (EC, 2010a, 2010b, 2010c, 2011). However, they call for particular attention when the Europe 2020 goal is translated into a regional setting.

In particular, our results suggest that "one-size-fits-all" policy goals are neither convincing nor efficient when applied at the regional level. In fact, R\&D investments are not the only channels through which regions grow. Our results show that the elasticity of GDP growth to innovation is much higher and less strongly differentiated among groups of regions than in the case of GDP growth elasticity to R\&D, and less formal knowledgeintensive regions can achieve GDP growth elasticity to innovation comparable with that of more knowledge-intensive regions.

In normative terms, these results are closely in line with the current debate on smart specialization (Foray, 2009; McCann and Ortega-Argilés, 2011; Barca, McCann, and Rodríguez-Pose, 2012; Camagni and Capello, 2013) calling for ad hoc, thematically/regionally focused innovation policies. This debate strongly emphasizes that policies must be embedded in the local reality, in local assets, and strategic design capabilities, and that they must ensure the achievement of external knowledge through strong and virtuous linkages with the external world (McCann and Ortega-Argilés, 2011). However, this is not enough: a "smart innovation" strategy must take a step forward by taking the R\&D element into consideration but adapting the two concepts of "embeddedness" and "connectedness" to the specificities of each "mode (pattern) of innovation," some of them not necessarily linked to the invention-innovation-growth logical path.

In this regard, smart innovation policies have recently been proposed (Camagni and Capello, 2013). These are defined as those policies able to increase the innovation capability of an area and to enhance local expertise in knowledge production and use. Such policies should not only act on local specificities and on the characteristics, strengths, and weaknesses of already established innovation patterns in each region; they should also look for targeted interventions-appropriate to each single territorial innovation pattern-with the aim of reinforcing regional innovation processes and the virtuous aspects that characterize each pattern, and of upgrading the local specialization and diversifying it into related technological fields.

"Smart innovation policies" designed according to these principles and guidelines could be conceptually and operationally sound responses to the need for renewed policy tools able to attain the goals of smart growth and Innovation Union (EC, 2010a, 2010b, 2010c, 2011), doing so consistently with the "smart specialization strategy" proposed by DG Research and the necessary place-based reform of the EU regional policy advocated by the Barca Report and the recent documents of DG Regio. 


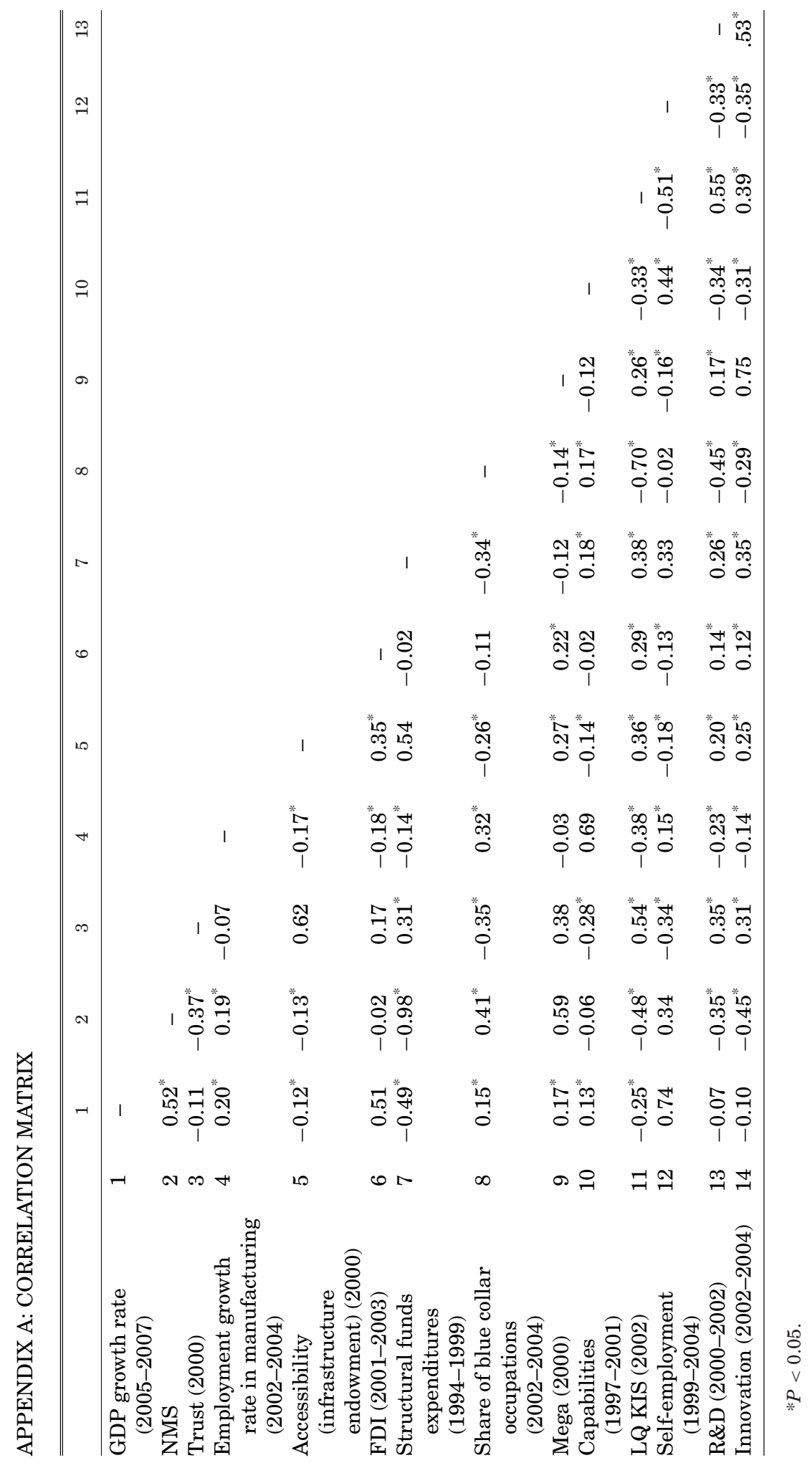




\section{APPENDIX B: ROBUSTNESS CHECK}

2SLS instrumental variable techniques were used to control for potential sources of endogeneity. In accordance with the focus of the paper, this empirical strategy was applied to the $R \& D$ variable, but it could not be pursued for the innovation variable owing to the lack of data. Therefore, only models 1 of Table 3 was estimated by 2SLS; R\&D was instrumented by using lagged values, as is customary in the growth literature in the absence of adequate instruments correlated to the explanatory variables but indirectly correlated to the dependent variable (Temple, 1999).

Table B1 reports the estimates of the second stage. The results are qualitatively unchanged. Interestingly, the Durbin-Wu-Hausman test does not allow rejection of the null hypothesis that the regressor is exogenous, suggesting that endogeneity is not a major concern in the estimates of Table 3, and therefore that OLS estimates are preferable to 2SLS.

TABLE B1: Determinants of GDP Growth Rate (2005-2007): 2SLS Estimates

Dependent Variable:

GDP growth rate (2005-2007)

Employment growth rate in manufacturing (2002-2004)

NMS

Trust (2000)

Accessibility (infrastructure endowment) (2000)

FDI (2001-2003)

Structural funds expenditures (1994-1999)

Share of blue collar occupations (2002-2004)

Capabilities (1997-2001)

Mega (2000)

LQ KIS (2002)

Self-employment (1999-2004)

R\&D (2000-2002)

Constant

$R^{2}$

Durbin-Wu-Hausman Test

$P$-value

Observations 


\section{REFERENCES}

Abramowitz, Moses. 1986. “Catching Up, Forging Ahead, and Falling Behind,” Journal of Economic History, 46(2), 386-406.

Acemoglu, Daron, Philippe Aghion, and Fabrizio Zilibotti. 2006. "Distance to Frontier, Selection, and Economic Growth," Journal of the European Economic Association, 4(1), 37-74.

Acs, Zoltan J. and Catherine Armington. 2004. "The Impact of Geographic Differences in Human Capital on Service Firm Formation Rate," Journal of Urban Economics, 56(2), 244-278.

- (eds.). 2006. Entrepreneurship, Geography and American Economic Growth. Cambridge, UK: Cambridge University Press.

Acs, Zoltan J., David B. Audretsch, and Maryann P. Feldman. 1994. "R\&D Spillovers and Recipient Firm Size," Review of Economics and Statistics, 76(2), 336-340.

Acs, Zoltan J., Luc Anselin, and Attila Varga. 2002. "Patents and Innovation Counts as Measures of Regional Production of New Knowledge," Research Policy, 31, 1069-1085.

Acs, Zoltan J. and Attila Varga. 2005. "Entrepreneurship, Agglomeration and Technological Change," Small Business Economics, 24, 323-334.

Aghion, Philippe and Peter Howitt. 1998. Endogenous Growth Theory. Cambridge, MA: MIT Press.

Almeida, Paul and Bruce Kogut. 1999. "Localization of Knowledge and the Mobility of Engineers in Regional Networks," Management Science, 45(7), 905-917.

Anselin, Luc. 1988. Spatial Econometrics: Methods and Models. Dordrecht: Kluwer

Anselin, Luc, Attila Varga, and Zoltan J. Acs. 1997. "Local Geographic Spillovers between University Research and High Technology Innovations," Journal of Urban Economics, 42(3), 422-448.

2000. "Geographic and Sectoral Characteristics of Academic Knowledge Externalities," Papers in Regional Science, 74(4), 435-443.

Archibugi, Daniele and Alberto Coco. 2005. "Measuring Technological Capabilities at The Country Level: A Survey and a Menu for Choice," Research Policy, 34(2), 175-194.

Armington, Catherine and Zoltan J. Acs. 2002. "The Determinant in Regional Variation in New Firm Formation," Regional Studies, 36(1), 33-45.

Asheim, Bjørn T. and Høgni K. Hansen. 2009. "Knowledge Bases, Talents and Contexts. On the Usefulness of the Creative Class Approach in Sweden,” Economic Geography, 85(4), 425-442.

Asheim, Bjørn T. and Lars Coenen. 2005. "Knowledge Bases and Regional Innovation Systems: Comparing Nordic Clusters," Research Policy, 34(8), 1173-1190.

Audretsch, David B. and Maryann P. Feldman. 1996. "R\&D Spillovers and the Geography of Innovation and Production," American Economic Review, 86(3), 630-640.

Autant-Bernard, Corinne. 2001. "Science and Knowledge Flows: Evidence from the French Case," Research Policy, 30(7), 397-422.

Badinger, Harald and Gabriele Tondl. 2002. "Trade, Human Capital and Innovation: The Engines of European Regional Growth in the 1990s," ERSA Conference Paper, ersa02p043

Barca, Fabrizio, Philip McCann, and Andrés Rodríguez-Pose. 2012. "The Case for Regional Development Intervention: Place-Based versus Place-Neutral Approaches," Journal of Regional Science, 52(1), 134-152.

Basile, Roberto, Roberta Capello, and Andrea Caragliu. 2012. "Technological Interdependence and Regional Growth in Europe: Proximity and Synergy in Knowledge Spillovers," Papers in Regional Science, 91(4), 697722.

Beaudry, Cathrine and Andrea Schiffauerova. 2009. "Who's Right, Marshall or Jacobs? The Localization vs Urbanization Debate," Research Policy, 38, 318-337.

Boschma, Ron A. 2005. "Proximity and Innovation. A Critical Survey," Regional Studies, 39(1), 61-74

Boschma, Ron A. and Simona Iammarino. 2009. "Related Variety, Trade Linkages, and Regional Growth in Italy," Economic Geography, 85(3), 289-311.

Breschi, Stefano and Francesco Lissoni. 2009. "Mobility of Inventors and Networks of Collaboration: An Anatomy of Localised Knowledge Flows," Journal of Economic Geography, 9, 439-468.

Buenstorf, Guido. 2009. "Is Commercialization Good or Bad for Science? Individual-Level Evidence from the Max Planck Society,” Research Policy, 38(2), 281-292.

Camagni, Roberto. 1991. "Technological Change, Uncertainty and Innovation Networks: Towards Dynamic Theory of Economic Space," in Camagni, R. (ed.), Innovation Networks: Spatial Perspectives. London: Belhaven-Pinter, pp. 121-144.

Camagni, Roberto and Roberta Capello. 2013. "Regional Innovation Strategies and the EU Regional Policy Reform: Towards Smart Innovation Policies," Growth and Change, 44(2), 355-389.

Capello, Roberta. 1994. Spatial Economic Analysis of Telecommunications Network Externalities. Ashgate: Aldershot.

\footnotetext{
Processes," Regional Studies, 33(4), 353-365.
} 
2009. "Spatial Spillovers and Regional Growth: A Cognitive Approach," European Planning Studies, 17(5), 639-658.

Capello, Roberta and Andrea Caragliu. 2012. "Proximities and the Intensity of Scientific Relations," Paper Presented at the International Tinbergen Institute Workshop 2012, Amsterdam.

Capello, Roberta, Andrea Caragliu, and Camilla Lenzi. 2012. "Is innovation in Cities a Matter of Knowledge Intensive Business Services? An Empirical Investigation," Innovation: The European Journal of Social Science Research, 25(2), 147-170.

Capello, Roberta and Camilla Lenzi. 2013a. "Territorial Patterns of Innovation and Economic Growth in European Regions," Growth and Change, 44(2), 195-227.

2013b. "The Knowledge-Innovation Nexus in European Regions," in Capello Roberta and Lenzi Camilla (eds.), Territorial Patterns of Innovation. An Inquiry on the Knowledge Economy in European Regions. Oxford: Routledge, pp. 93-126.

Capello, Roberta, Roberto Camagni, Ugo Fratesi, and Barbara Chizzolini. 2008. Modelling Regional Scenarios for an Enlarged Europe. Berlin: Springer Verlag

Charlot, Sylvie, Riccardo Crescenzi, and Antonio Musolesi. 2012. "An 'Extended' Knowledge Production Function Approach to the Genesis of Innovation in the European Regions," WP GAEL, 2012-06, http://www.grenoble.inra.fr/Docs/pub/A2012/gael2012-06.pdf. Accessed 9/26/2012.

Cohen, Wesley M. and Daniel A. Levinthal. 1990. "Absorptive Capacity: A New Perspective on Learning and Innovation," Administrative Science Quarterly, 35(1), 128-152.

Conte, Andrea and Marco Vivarelli. 2005. "One or Many Knowledge Production Functions? Mapping Innovative Activity Using Microdata,” IZA Discussion Papers, 1878.

Cooke, Philip, Bjørn Asheim, Ron A. Boschma, Ron Martin, Dafna Schwartz, and Franz Tödtling (eds.). 2011. Handbook of Regional Innovation and Growth. Cheltenham: Edward Elgar.

Crescenzi, Riccardo. 2005. "Innovation and Regional Growth in the Enlarged Europe: The Role of Local Innovative Capabilities, Peripherality, and Education," Growth and Change, 36(4), 471-507.

Duranton, Gilles and Diego Puga. 2000. "Diversity and Specialisation in Cities. Why, Where and When Does it Matter?" Urban Studies, 37(3), 533-555.

Ergas, Henry. 1987. “Does Technology Policy Matter?” In Bruce R. Guile and Harvey Brooks (eds.), Technology and Global Industry, Companies and Nations in the World Economy. Washington DC: National Academy Press, pp. 191-245.

Ertur, Cem and Wilfried Koch. 2011. "A Contribution to the Theory and Empirics of Schumpeterian Growth with Worldwide Interactions," Journal of Economic Growth, 16(3), 215-255.

European Commission. 2010a. "Europe 2020: A Strategy for Smart, Sustainable and Inclusive Growth," COM(2010) 2020 Final, Brussels, March 3, 2010.

2010b. "Europe 2020 Flagship Initiative Innovation Union, Communication from the Commission to the European Parliament, the Council, the European Economic and Social Committee and the Committee of the Regions," SEC(2010) 1161, COM(2010) 546 Final, October 6, 2010.

. 2010c. "Regional Policy Contributing to Smart Growth in Europe, Communication from the Commission to the European Parliament, the Council, the European Economic and Social Committee and the Committee of the Regions," SEC(2010)1183, COM(2010)553 Final, Brussels, October 6, 2010.

2011. "Horizon 2020: The Framework Programme for Research and Innovation, Communication from the Commission to the European Parliament, the Council, the European Economic and Social Committee and the Committee of the Regions," SEC(2011)1427 Final, COM(2011) 808, Brussels, November, 2011.

2012. "Knowledge-intensive business services in Europe," Directorate-General for Research and Innovation. Available at: http://ec.europa.eu/research/innovation-union/pdf/knowledge_intensive_business_services_in_ europe_2011.pdf. Accessed 1/29/2013.

Fagerberg, Jan E. 2003. "Schumpeter and the Revival of Evolutionary Economics: An Appraisal of the Literature," Journal of Evolutionary Economics, 13, 125-159.

Fagerberg, Jan E., Martin Shrolec, and Mark Knell. 2007. "The Competitiveness of Nations: Why Some Countries Prosper While Others Fall Behind,” World Development, 35(10), 1595-1620.

Fagerberg, Jan E. and Martin Shrolec. 2008. "National Innovation Systems: Capabilities and Economic Development," Research Policy, 37(9), 1417-1435.

Fagerberg, Jan E., Martin Shrolec, and Bart Verspagen. 2010. "The Role of Innovation in Development," Review of Economics and Institutions, 1(2), 1-29.

Feldman, Maryann P. 1994. The Geography of Innovation. Boston, MA: Kluwer.

Foray, Dominique. 2009. "Understanding Smart Specialisation," in D. Pontikakis, D. Kyriakou, and R. van Bavel (eds.), The Question of R\&D Specialisation, JRC, European Commission. Brussels: Directoral General for Research, pp. 19-28.

Frenken, Koen, Frank G. van Oort, and Thijs Verburg. 2007. "Related Variety, Unrelated Variety and Regional Economic Growth," Regional Studies, 41(5), 685-697. 
Fritsch, Michael and Oliver Falck. 2007. "New Firm Formation by Industry Over Space and Time: A Multidimensional Analysis," Regional Studies, 41(2), 157-172.

Fritsch, Michael and Viktor Slavetch. 2007. "Universities and Innovation in Space," Industry and Innovation, $14(2), 201-218$.

Giuliani, Elisa. 2007. "The Selective Nature of Knowledge Networks in Clusters: Evidence from the Wine Industry," Journal of Economic Geography, 7, 139-168.

Griliches, Zvi. 1990. “Patent Statistics as Economic Indicators: A Survey,” Journal of Economic Literature, 28(4), 1661-1707.

Grossman, Gene M. and Elhanan Helpman. 1990. "Trade, Innovation, and Growth,” American Economic Review, $80,86-91$.

Hollanders, Hugo, Stefano Tarantola, and Alexander Loschky. 2009. "Regional Innovation Scoreboard (RIS) 2009," Pro Inno Europe Paper n. 14, Entreprise and Industry Magazine, Brussels. Available at: http://www.proinno-europe.eu/page/regional-innovation-scoreboard.06/04/2010. Accessed 4/6/2010.

Howitt, Peter. 2000. "Endogenous Growth and Cross-Country Income Differences," American Economic Review, 90, 829-846.

Iammarino, Simona. 2005. "An Evolutionary Integrated View of Regional Systems of Innovation: Concepts, Measures and Historical Perspectives,” European Planning Studies, 13(4), 497-519.

Iammarino, Simona and Philip McCann. 2006. "The Structure and Evolution of Industrial Clusters: Transactions, Technology and Knowledge Spillovers," Research Policy, 35, 1018-1036.

IAREG. 2010. "Intangible Assets and Regional Economic Growth, Scientific Executive Summary." Available at: http://www.iareg.org/. Accessed 2/10/2012.

Jaffe, Adam B. 1986. "Technological Opportunity and Spillovers of R\&D: Evidence from Firms' Patents, Profits, and Market Value," American Economic Review, 76, 984-1001.

. 1989. "Real Effects of Academic Research," American Economic Review, 79(5), 957-970.

Jaffe, Adam B., Manuel Trajtenberg, and Rebecca Henderson. 1993. "Geographic Localization of Knowledge Spillovers as Evidenced by Patent Citations," The Quarterly Journal of Economics, 108(3), 577-598.

Keeble, David. 1990. "Small Firms, Innovation and Regional Development in Britain in the 1990s," Regional Studies, 31(3), 281-293.

Keeble, David and Frank Wilkinson. 1999. "Collective Learning and Knowledge Development in the Evolution of Regional Clusters of High-Technology SMEs in Europe,” Regional Studies, 33(4), 295-303.

. 2000. High Technology Clusters, Networking and Collective Learning in Europe. Ashgate: Aldershot.

Kim, Linsu. 1980. "Stages of Development of Industrial Technology in a Developing Country: A Model," Research Policy, 9(3), 254-277.

- 1997. Imitation to Innovation: The Dynamics of Korea's Technological Learning. Harvard: Harvard University Press.

Krugman, Paul R. 1991. Geography and Trade. Cambridge, MA: MIT Press.

Licht, Georg. 2009. "How to Better Diffuse Technologies in Europe," Knowledge Econonomists Policy Brief, 7, 1-5.

Lundvall, Bengt A. and Björn Johnson. 1994. "The Learning Economy," Journal of Industry Studies, 1(1), $23-42$.

Marrocu, Emanuela, Raffaele Paci, and Stefano Usai. 2013. "Productivity Growth in the Old and New Europe: The Role of Agglomeration Externalities," Journal of Regional Science, 53(3), 418-442.

McCann, Philip and Raquel Ortega-Argilés. 2011. "Smart Specialisation, Regional Growth and Applications to EU Cohesion Policy,” Document de treball de l'IEB 2011/14, Institut d'Economia de Barcelona.

Moreno, Rosina, Raffaele Paci, and Stefano Usai. 2005. "Spatial Spillovers and Innovation Activity in European Regions," Environment and Planning A, 37(10), 1793-1812.

Parker, Simon C. 2005. "Explaining Regional Variations in Entrepreneurship as Multiple Equilibria," Journal of Regional Science, 45(4), 829-850.

Perloff, Harvey S. 1957. "Interrelations of State Income and Industrial Structure," Review of Economics and Statistics, 39(2), 162-171.

Perloff, Harvey S., Edgar S. Dunn, Eric E. Lampard, and Richar F. Muth. 1960. Region, Resources and Economic Growth. Baltimore, MD: John Hopkins University Press

Perrin Jean, Claude. 1995. "Apprentissage collectif, territoire et milieu innovateur: un nouveau paradigme pour le développement," in Ferrão João (ed.), Políticas de inovação e desenvolvimento regional et local. Edição do Instituto de Ciencias Sociais de Universidade de Lisboa. [Republished in Camagni Roberto and Maillat Denis (eds.) (2006), Milieux innovateurs, Paris,Economica-Anthropos, p. 99-128.]

Piergiovanni, R., Enrico Santarelli, and Marco Vivarelli. 1997. "From Which Source Do Small Firm Derive Their Innovative Inputs? Some Evidence from Italian Provinces," Review of Industrial Organizaition, 12, 243-258.

Ramajo, Julián, Miguel M. Márquez, Geoffrey J. D. Hewings, and María. M. Salinas. 2008. "Spatial Heterogeneity and Interregional Spillovers in the European Union: Do Cohesion Policies Encourage Convergence Across Regions?" European Economic Review, 52(3), 551-567.

Rodríguez-Pose, Andrés and Ugo Fratesi. 2004. "Between Development and Social Policies: The Impact of European Structural Funds in Objective 1 Regions," Regional Studies, 38(1), 97-113. 
Rodríguez-Pose, Andrés and Riccardo Crescenzi. 2008. "Research and Development, Spillovers, Innovation Systems, and the Genesis of Regional Growth in Europe," Regional Studies, 42(1), 51-67.

Romer, Paul M. 1990. "Endogenous Technical Change," Journal of Political Economy, 98, 71-102.

Schumpeter, Joseph A. 1934. The Theory of Economic Development. London: Oxford University Press. 1942. Capitalism, Socialism and Democracy. New York: Harper and Row.

Singh, Jasjit. 2005. "Collaborative Networks as Determinants of Knowledge Diffusion Patterns," Management Science, 51(5), 756-770.

Sterlacchini, Alessandro. 2008. "R\&D, Higher Education and Regional Growth: Uneven Linkages among European Regions," Research Policy, 37, 1096-1107.

Sternberg, Rolf. 1996a. "Reasons for the Genesis of High-tech Regions: Theoretical Explanation and Empirical Evidence," Geoforum, 27(2), 205-223.

. "Government R\&D Expenditure and Space: Empirical Evidence for Five Advanced Industrial Economies," Research Policy, 25, 741-758.

Storey, David J. and Zoltan J. Acs. 2004. "Introduction: Entrepreneurship and Economic Development," Regional Studies, 38(8), 871-877.

Tabellini, Guido. 2008. "Institutions and Culture: Presidential Address," Journal of the European Economic Association, 6, 255-294.

Temple, Jonathan. 1999. “The New Growth Evidence,” Journal of Economic Literature, 37, 112-156.

Trippl, Michaela. 2010. "Developing cross-Border Regional Innovation Systems: Key Factors and Challenges," Tijdschrift voor Economische en Sociale Geographie (TESG), 101(2), 150-160.

Varga, Attila. 2000. "Local Academic Knowledge Transfers and the Concentration of Economic Activity," Journal of Regional Science, 40(2), 289-309.

. 2006. "The Spatial Dimension of Innovation and Growth: Empirical Research Methodology and Policy Analysis," European Planning Studies, 14(9), 1171-1186.

. (ed.) 2009. Universities, Knowledge Transfer and Regional Development: Geography, Entrepreneurship and Policy. Cheltenham: Edward Elgar Publishers.

Zucker, Lynne G., Michael R. Darby, and Marilynn B. Brewer. 1998. "Intellectual Human Capital and the Birth of US Biotechnology Enterprises,” American Economic Review, 88(1), 290-306. 